\title{
Changes in the Saltwater Interface Corresponding to the Installation of a Seepage Barrier Near Lake Okeechobee, Florida
}

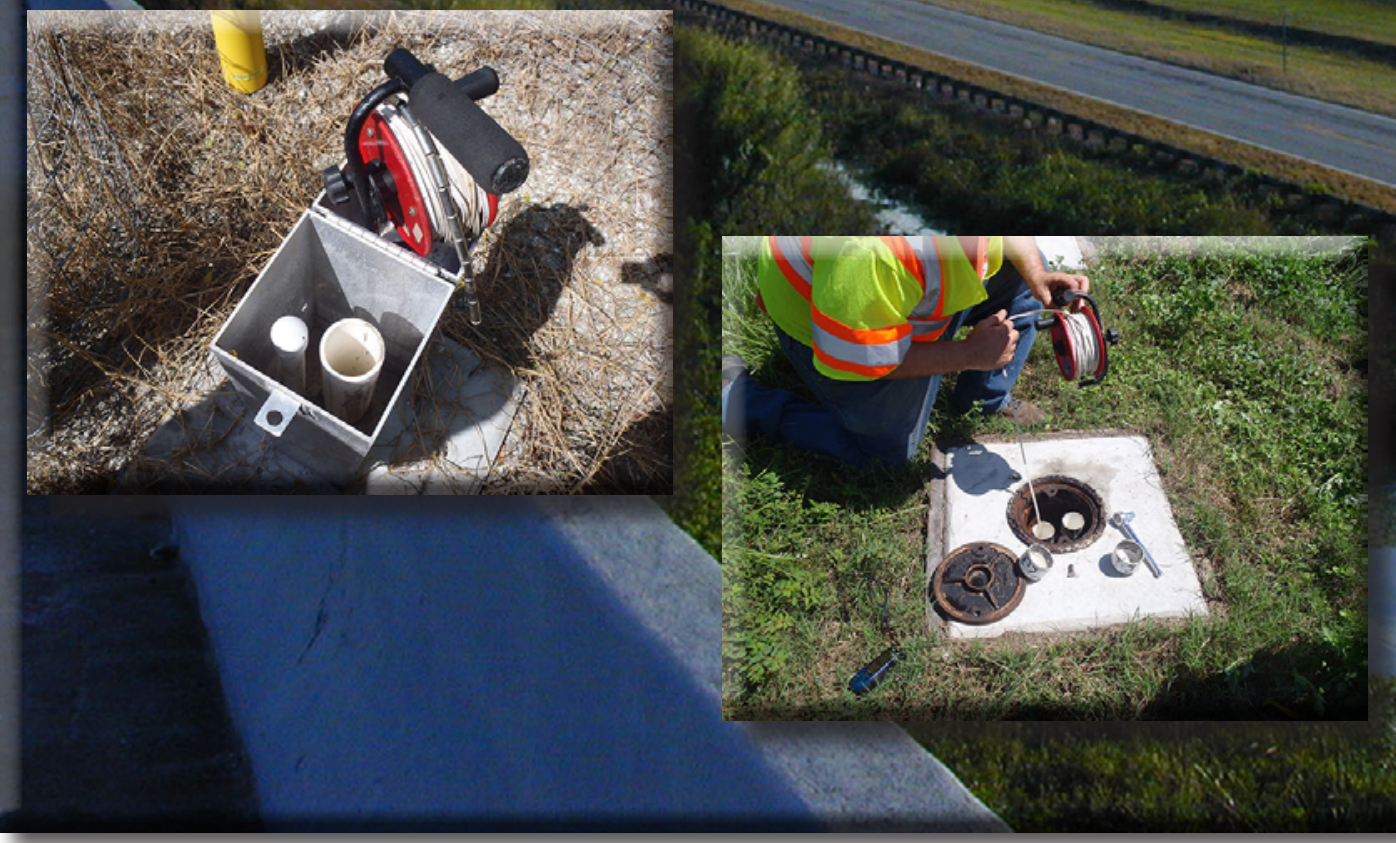

Open-File Report 2014-1256

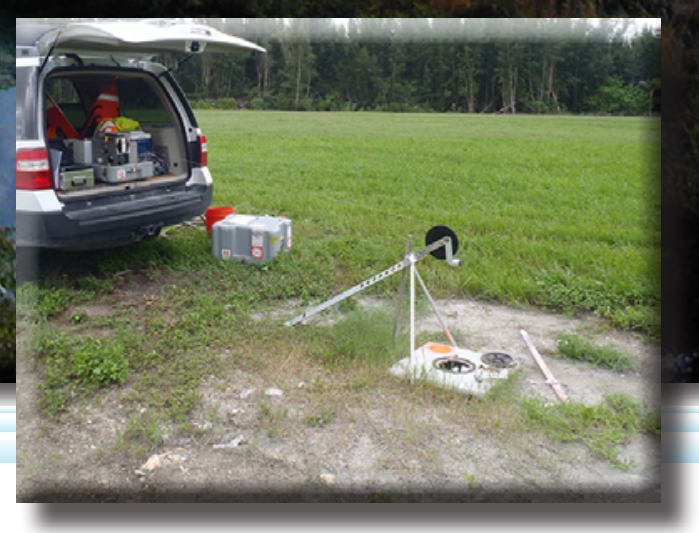

U.S. Department of the Interior

U.S. Geological Survey 
Cover. Background photograph—Lake Okeechobee by U.S. Geological Survey, South Florida Information Access [SOFIA]. Inset photographs from left to right-Monitoring well used to collect water-quality data; technician measuring the water level in a well; collection of an electromagnetic induction log from a well (Jeffrey F. Robinson, U.S. Geological Survey). 


\section{Changes in the Saltwater Interface Corresponding to the Installation of a Seepage Barrier Near Lake Okeechobee, Florida}

By Scott T. Prinos and Robert Valderrama

Open-File Report 2014-1256 


\title{
U.S. Department of the Interior SALLY JEWELL, Secretary
}

\section{U.S. Geological Survey Suzette M. Kimball, Acting Director}

\author{
U.S. Geological Survey, Reston, Virginia: 2015
}

For more information on the USGS - the Federal source for science about the Earth, its natural and living resources, natural hazards, and the environment, visit http://www.usgs.gov or call 1-888-ASK-USGS.

For an overview of USGS information products, including maps, imagery, and publications, visit http://www.usgs.gov/pubprod

To order this and other USGS information products, visit http://store.usgs.gov

Any use of trade, firm, or product names is for descriptive purposes only and does not imply endorsement by the U.S. Government.

Although this information product, for the most part, is in the public domain, it also may contain copyrighted materials as noted in the text. Permission to reproduce copyrighted items must be secured from the copyright owner.

Suggested citation:

Prinos, S.T., and Valderrama, Robert, 2015, Changes in the saltwater interface corresponding to the installation of a seepage barrier near Lake Okeechobee, Florida: U.S. Geological Survey Open-File Report 2014-1256, 24 p., http://dx.doi.org/10.3133/ofr20141256.

ISSN 2331-1258 (online) 


\section{Acknowledgments}

The authors would like to acknowledge the substantial contributions of Mark Shafer and Hwai-Ping (Pearce) Cheng of the U.S. Army Corps of Engineers who provided data and insights that were crucial to understanding changes in the saltwater interface near the Herbert Hoover

Dike, and differences in the quality of the information collected from short-screened, and longscreened wells. Substantive reviews of the report were also provided by Hwai-Ping (Pearce) Cheng, Mark Shafer, and Russ Weeks of the U.S. Army Corps of Engineers, and Mike Deacon, David Fitterman, emeritus, and Mike Wacker, of the U.S. Geological Survey. 



\section{Contents}

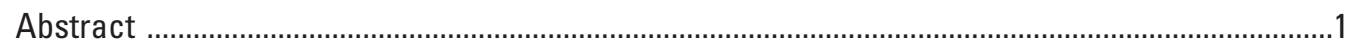

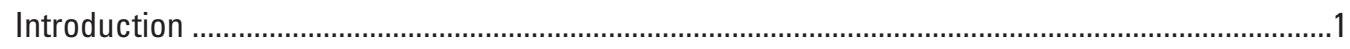

Methods

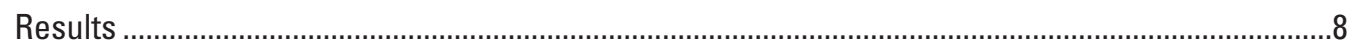

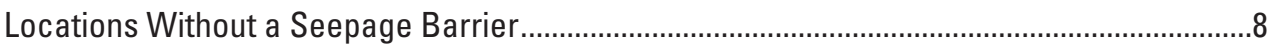

Locations With a Seepage Barrier ..................................................................................12

Comparison of Information From Short-Screened and Long-Screened Wells ........................17

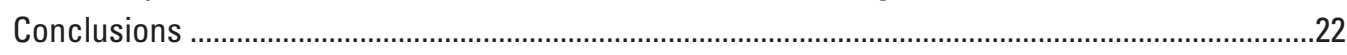

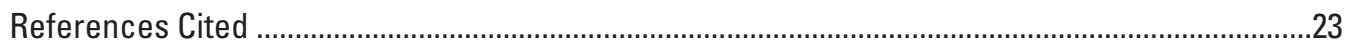

Appendix 1. Results of water samples from selected long-screened interval monitoring wells...............................................................ttp://pubs.usgs.gov/of/2014/1256/

Appendix 2. Results of water samples from selected short-screened interval monitoring wells.............................................................http://pubs.usgs.gov/of/2014/1256/

\section{Figures}

1. Map showing location of Lake Okeechobee, seepage barrier reaches, and monitoring wells installed to monitor the depth of the saltwater interface.

2. Idealized section through the Herbert Hoover Dike showing the freshwater/ saltwater mixing zone and the 1,000-milligram-per-liter isochlor

3. Diagram of short-screened interval monitoring wells used for water sampling and collection of time series electromagnetic-induction log datasets.....

4. Graphs showing chloride concentration of water samples from shallow, short-screened monitoring wells near Lake Okeechobee, Florida

5. Graph of time series electromagnetic-induction log (TSEMIL) dataset from monitoring well PB-1821, generally showing only minor temporal changes in the bulk conductivity of the aquifer.

6. Graphs showing comparison of the time series electromagnetic-induction $\log$ (TSEMIL) dataset from monitoring well GL-332, and the total dissolved solids concentration of water samples collected from monitoring well HHD10-R2-MW4F

7. Graphs showing comparison of the time series electromagnetic-induction $\log$ (TSEMIL) dataset from well HE-1145, and the total dissolved solids concentration of water samples collected from well HHD10-R2-MW18F.

8. Graphs showing comparison of the time series electromagnetic-induction $\log$ (TSEMIL) dataset from monitoring well PB-1822, and the total dissolved solids concentration of water samples collected from monitoring well HHD10-R3-MW18F

9. Graph showing time series electromagnetic-induction log dataset from monitoring well PB-1817 showing changes in the bulk conductivity of the aquifer.

10. Graph showing time series electromagnetic-induction log (TSEMIL) dataset from monitoring well PB-1815 showing changes in the bulk conductivity of the aquifer 
11. Graph showing time series electromagnetic-induction log (TSEMIL) dataset from monitoring well PB-1816 showing changes in the bulk conductivity of the aquifer.

12. Graphs showing comparison of the time series electromagnetic-induction $\log$ (TSEMIL) dataset from well PB-1818, and the total dissolved solids concentration of water samples collected from well HHD08-R1C-MW8D, including detailed depictions of the TSEMIL dataset from $40-65 \mathrm{ft}$, and $75-100 \mathrm{ft}$.........18

13. Graph showing time series electromagnetic-induction log dataset from monitoring well PB-1819 showing changes in the bulk conductivity of the aquifer.

14. Graph showing time series electromagnetic-induction log (TSEMIL) dataset from monitoring well PB-1820 showing temporal changes in the bulk conductivity of the aquifer

15. Graph showing total dissolved solids concentration of water samples collected from monitoring well HHD08-R1D-MW5D.

\section{Tables}

1. Design of monitoring wells, and depth and date of completion of seepage barrier .........4

2. Design of long-screened monitoring wells, and depth and date of completion of seepage barrier.

\section{Conversion Factors}

Inch/Pound to International System of Units

\begin{tabular}{lcl}
\hline \multicolumn{1}{c}{ Multiply } & \multicolumn{1}{c}{ By } & \multicolumn{1}{c}{ To obtain } \\
\hline inch (in.) & \multicolumn{2}{c}{ Length } \\
inch (in.) & 2.54 & centimeter $(\mathrm{cm})$ \\
foot (ft) & 25.4 & millimeter $(\mathrm{mm})$ \\
\hline mile (mi) & 0.3048 & meter $(\mathrm{m})$ \\
\hline & 1.609 & kilometer $(\mathrm{km})$ \\
\hline siemens per meter $(\mathrm{S} / \mathrm{m})$ & Electrical conductivity \\
siemens per meter $(\mathrm{S} / \mathrm{m})$ & 1,000 & millisiemens per meter $(\mathrm{mS} / \mathrm{m})$ \\
\hline
\end{tabular}

Electrical conductivity $\sigma$ in siemens per meter $[\mathrm{S} / \mathrm{m}]$ can be converted to electrical resistivity $\rho$ in ohm-meters [ohm m] as follows: $\rho=1 / \sigma$.

Electrical conductivity $\sigma$ in millisiemens per meter $[\mathrm{mS} / \mathrm{m}]$ can be converted to electrical resistivity $\rho$ in ohm-meters [ohm m] as follows: $\rho=1,000 / \sigma$.

Electrical conductivity $\sigma$ in microsiemens per centimeter $[\mu \mathrm{S} / \mathrm{cm}]$ can be converted to electrical resistivity $\rho$ in ohm-meters [ohm m] as follows: $\rho=10,000 / \sigma$.

Temperature in degrees Celsius $\left({ }^{\circ} \mathrm{C}\right)$ may be converted to degrees Fahrenheit $\left({ }^{\circ} \mathrm{F}\right)$ as follows:

$$
{ }^{\circ} \mathrm{F}=\left(1.8 \times{ }^{\circ} \mathrm{C}\right)+32
$$




\section{Datum}

Vertical coordinate information is referenced to the National Geodetic Vertical Datum of 1929 (NGVD 29).

Horizontal coordinate information is referenced to the North American Datum of 1983 (NAD 83).

Elevation, as used in this report, refers to distance above the vertical datum.

\section{Supplemental Information}

Specific conductance is given in microsiemens per centimeter at 25 degrees Celsius

$\left(\mu \mathrm{S} / \mathrm{cm}\right.$ at $\left.25^{\circ} \mathrm{C}\right)$.

Concentrations of chemical constituents in water are given in milligrams per liter (mg/L).

\section{Abbreviations}

$\begin{array}{ll}\text { EMI } & \text { electromagnetic induction } \\ \text { HHD } & \text { Herbert Hoover Dike } \\ \text { IAG } & \text { International Analytic Group } \\ \text { PVC } & \text { polyvinyl chloride } \\ \text { TDS } & \text { total dissolved solids } \\ \text { TSEMIL } & \text { time series electromagnetic-induction log (dataset) } \\ \text { USACE } & \text { U.S. Army Corps of Engineers } \\ \text { USGS } & \text { U.S. Geological Survey }\end{array}$





\title{
Changes in the Saltwater Interface Corresponding to the Installation of a Seepage Barrier Near Lake Okeechobee, Florida
}

\author{
By Scott T. Prinos and Robert Valderrama
}

\begin{abstract}
In 2011, the U.S. Geological Survey and the U.S. Army Corps of Engineers began monitoring the saltwater interface near Lake Okeechobee to evaluate changes in interface depth that could possibly be related to the repair of the Herbert Hoover Dike. A seepage barrier (or cut-off wall), installed by the U.S. Army Corps of Engineers, is a wall of grout designed to protect the Herbert Hoover Dike from internal erosion caused by the piping of water. The seepage barrier prevents water from flowing through or immediately under the dike by diverting the flow below the dike, into the surficial aquifer system. The seepage barrier extends below the saltwater interface in some areas. Monitoring consisted of collecting water samples and time series electromagnetic-induction log (TSEMIL) datasets from 10 well clusters, each of which have 1 shallow and 1 deep monitoring well, with 5- to 10-foot- (ft) long-screened intervals. The deep wells are 120 to $187 \mathrm{ft}$ deep, and the shallow wells are 44 to $100 \mathrm{ft}$ deep.

Changes in the depth of the saltwater interface were identified that correspond closely to the depth of the bottom of the seepage barrier. These changes may have been the consequence of changes in groundwater flow initiated by the seepage barrier installation. In areas of the dike where a seepage barrier had not been installed, or where the bottom of the seepage barrier is well above the saltwater interface, monitoring detected no changes in the depth of the saltwater interface.

At five of the monitoring-well cluster locations, a long-screened well was also installed for monitoring and comparison purposes. These long-screened wells are 160 to $200 \mathrm{ft}$ deep, and have open intervals ranging from 145 to $185 \mathrm{ft}$ in length. Water samples were collected at depth intervals of about 5 to $10 \mathrm{ft}$, using 3 -ft-long straddle packers to isolate each sampling interval. The results of monitoring conducted using these long-screened interval wells were generally too variable to identify any changes that might be associated with the seepage barrier. Samples from one of these long-screened interval wells failed to detect the saltwater interface evident in samples and TSEMIL datasets from a
\end{abstract}

collocated well cluster. This failure may have been caused by downward flow of freshwater from above the saltwater interface in the well bore.

\section{Introduction}

Lake Okeechobee is one of the largest freshwater lakes in the United States (fig. 1) and is surrounded by the Herbert Hoover Dike (HHD). Modifications to the HHD are being made to prevent its failure. The U.S. Army Corps of Engineers (USACE) constructed the HHD during the 1930s to prevent hurricane-induced floods, like those in 1926 and 1928, that killed a combined estimated total of 2,400 to 3,400 people (Lloyd's, 2010; U.S. Army Corps of Engineers, [n.d.]). The need for major repairs to the HHD became evident during 2004 and 2005 when Hurricanes Frances, Jeanne, and Wilma damaged the levee through erosion and seepage of water through or under the dike (Abtew and Iricanin, 2008). When this seepage occurs, it can lead to internal erosion of the dike by piping, defined as the removal of sand- and silt-sized particles by water seeping through the dike. Piping can lead to cavity formation, which in turn, may eventually cause the dike to collapse. Concerning seepage through and beneath the HHD, Bromwell and others (2006) reported that the "Herbert Hoover Dike has narrowly escaped failure from this process on several occasions, and we suspect that its condition may be worsening." The USACE began a project in 2007 to install a seepage barrier (or cut-off wall) to prevent water from seeping through or immediately under the dike (U.S. Army Corps of Engineers, 2013). The seepage barrier is a wall of grout that diverts the flow of water below the dike into the surficial aquifer system to prevent erosion by piping through the dike and immediately beneath it. The installation of the seepage barrier in the HHD around the lake is being done in stages over sections of the dike called "reaches" (fig. 1). Reaches 1A-1D of the seepage barrier were completed during October 2009-July 2012. Reaches 2 and 3 have not been installed at the time of this report. 


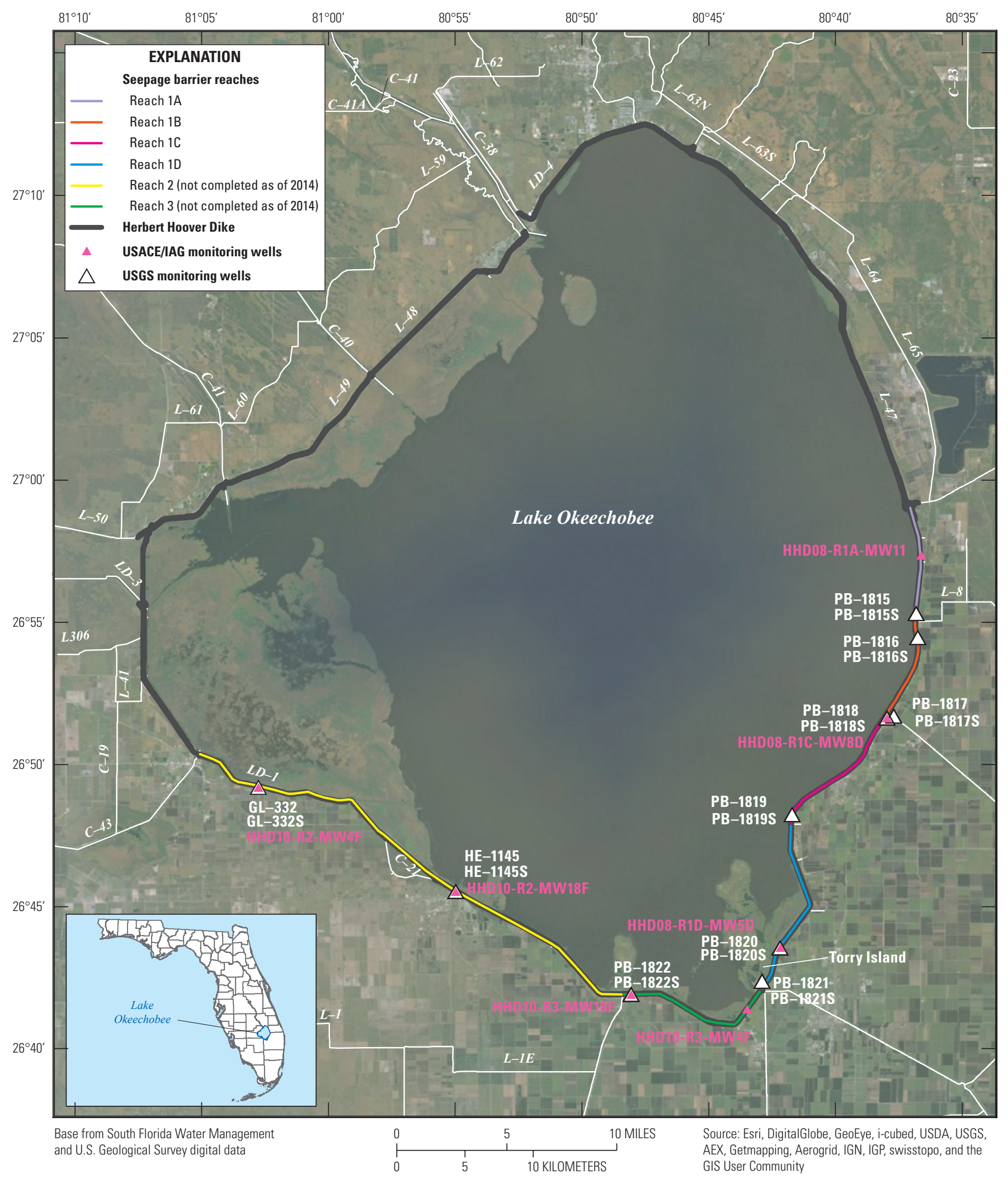

Figure 1. Location of Lake Okeechobee, seepage barrier reaches, and monitoring wells installed to monitor the depth of the saltwater interface. [IAG, International Analytic Group; USACE, U.S. Army Corps of Engineers; USGS, U.S. Geological Survey] 
The surficial aquifer system is a source of freshwater that is used for private water supply in some areas near Lake Okeechobee. Near the southern edge of the Lake, in Glades, Hendry, and Palm Beach Counties, the freshwater in the aquifer transitions to saltwater beginning at depths of 30 to 120 feet (ft). The ratios of strontium-87 to strontium- 86 in water samples of this saltwater indicate that it is most likely residual invaded or relict seawater (Reese and Wacker, 2009). In some areas, the seepage barrier extends to a depth near or below that of the saltwater interface. Groundwater flow diverted by the seepage barrier in these areas could possibly alter the distribution of saltwater in the surficial aquifer (fig. 2) and cause saltwater to intrude into areas that were previously fresh (fig. $2 B-C$ ).

Monitoring was initiated to determine if the interface was disturbed as groundwater flow was altered by the seepage barrier. A monitoring network was designed to detect changes in the depth and concentration of saltwater in the aquifer, using water samples to evaluate chloride concentration, and time series electromagnetic-induction log (TSEMIL) datasets to evaluate changes in bulk conductivity in the aquifer. Monitoring began in August 2011 and continues as of the writing of this report.

This report documents changes in the saltwater interface, likely, resulting from installation of a seepage barrier near Lake Okeechobee, Florida. Monitoring results from August 2011 through January 2014 are summarized herein and compared between locations where the seepage barrier was present or absent to determine the sources of apparent variation in aquifer salinity. Monitoring results from long- and short-screened monitoring wells are compared to evaluate the well design that provides the most reliable results.

\section{Methods}

The U.S. Geological Survey (USGS) monitored 20 shallow and deep, short-screened interval monitoring wells installed at 10 sites (fig. 1; table 1). The shallow and deep monitoring wells of each monitoring-well cluster are generally installed within the same borehole (fig. 3). Monitoring wells are cased with polyvinyl chloride (PVC) pipe and have 5- to 10 -ft screened intervals. The deep wells are 2 inches (in.) in diameter and between 120 and $187 \mathrm{ft}$ deep (table 1). The shallow wells are 0.75 -in. in diameter and are used to collect water samples, generally from near the top of the saltwater interface. When monitoring began, the saltwater interface was about 1 to $7 \mathrm{ft}$ below the bottom of the open intervals of wells GL-332S, PB-1819S, PB-1818S, PB-1821S, and PB-1822S, and 6 and $9 \mathrm{ft}$ above the open interval of $\mathrm{PB}-1816 \mathrm{~S}$ and PB-1817S, respectively (table 1). The top of the saltwater interface was about 27 to $67 \mathrm{ft}$ below the bottom of the open intervals of wells HE-1145S, PB-1815S, and PB-1820S when monitoring began. Most of the shallow wells are between 44 and $60 \mathrm{ft}$ deep, but wells PB-1820S and PB-1821S are 95 and $100 \mathrm{ft}$ deep, respectively. Water samples and TSEMIL datasets were collected from each well.
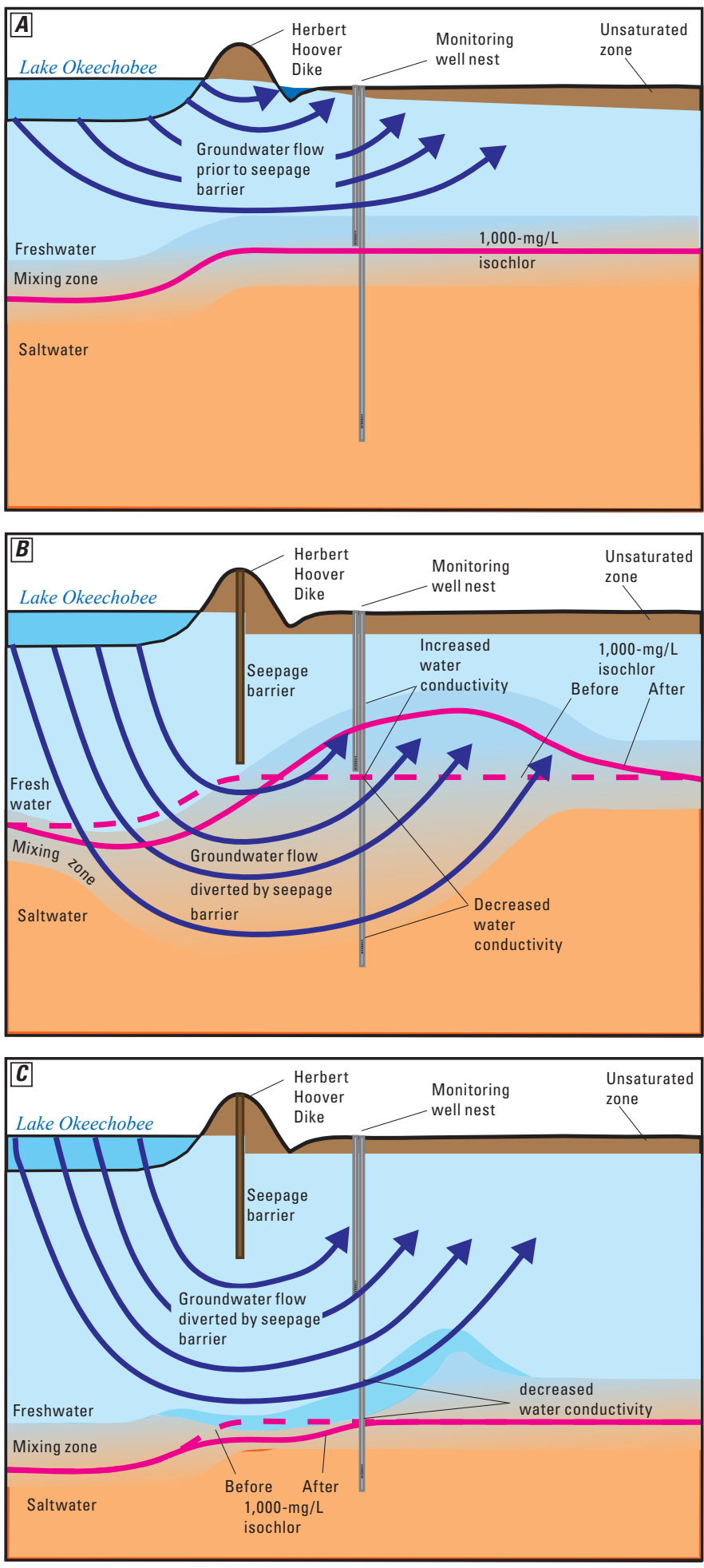

Figure 2. Idealized section through the Herbert Hoover Dike showing the freshwater/saltwater mixing zone and the 1,000-milligram-per-liter isochlor $(A)$ prior to the installation of the seepage barrier, and potential changes in the distribution of saltwater in the aquifer after installation of a seepage barrier that $(B)$ extends to a depth near to or below the mixing zone, and $(C)$ is completed to a depth well above that of the mixing zone. Diagram is not to scale. 
Table 1. Design of monitoring wells, and depth and date of completion of seepage barrier.

[--, no information; ft, foot; ID, Identifier; LS, land surface; HHD, Herbert Hoover Dike; NAD 83, North American Datum of 1983]

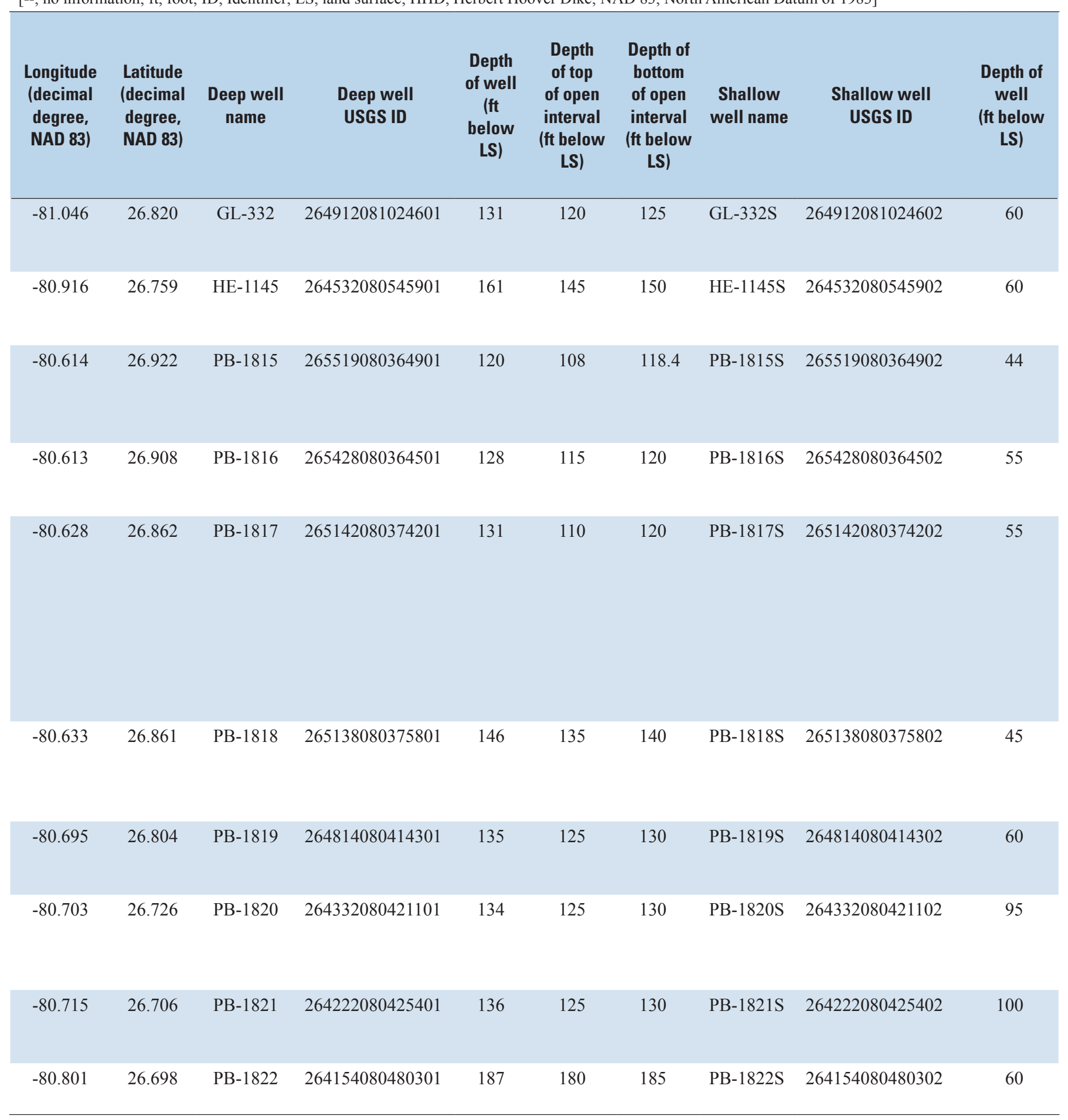


Table 1. Design of monitoring wells, and depth and date of completion of seepage barrier-Continued

[--, no information; ft, foot; ID, Identifier; LS, land surface; HHD, Herbert Hoover Dike; NAD 83, North American Datum of 1983]

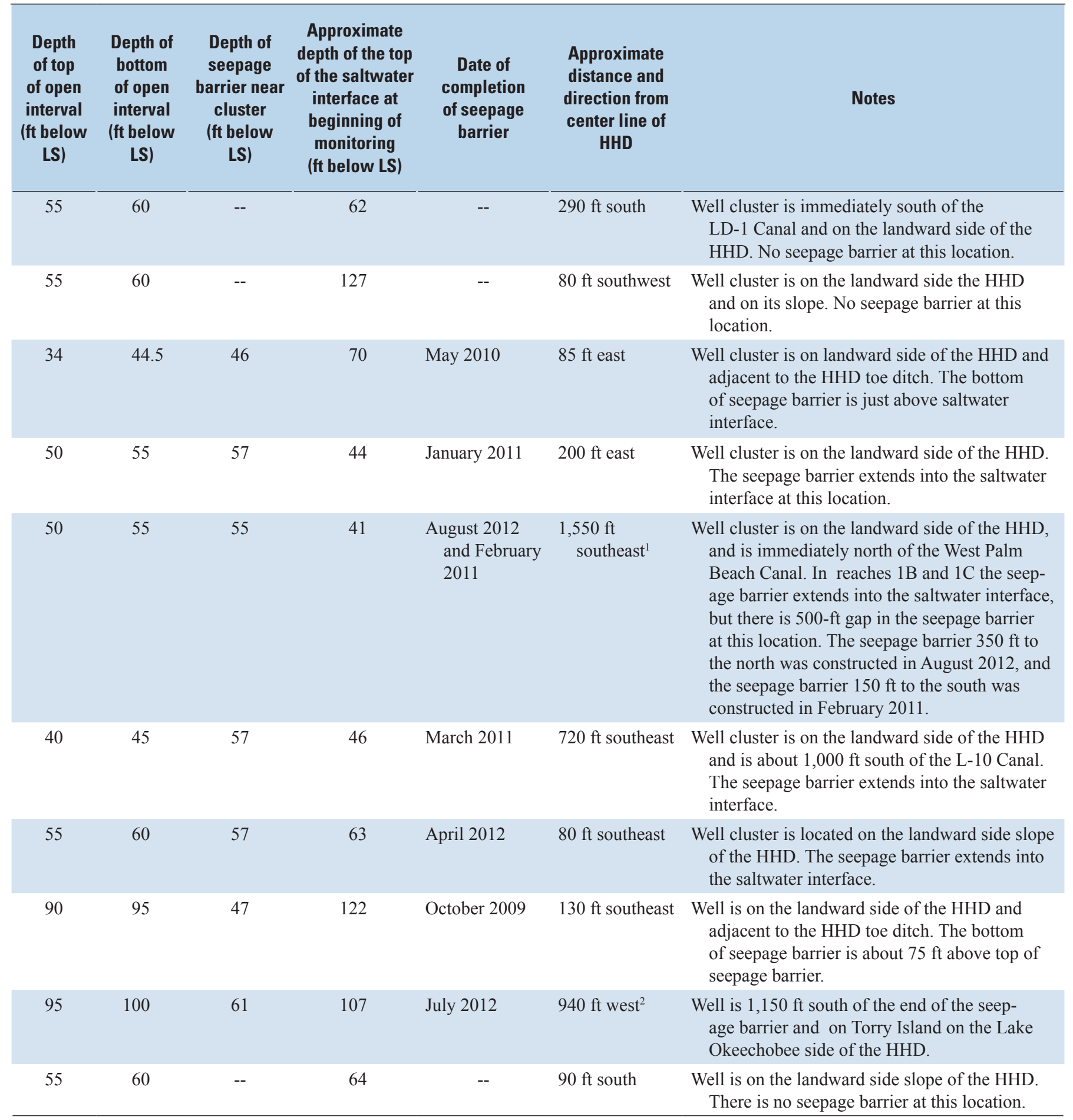

${ }^{1}$ There is a $500-\mathrm{ft}$ gap in the seepage barrier.

${ }^{2}$ Well cluster is on the lake side of the HHD. 


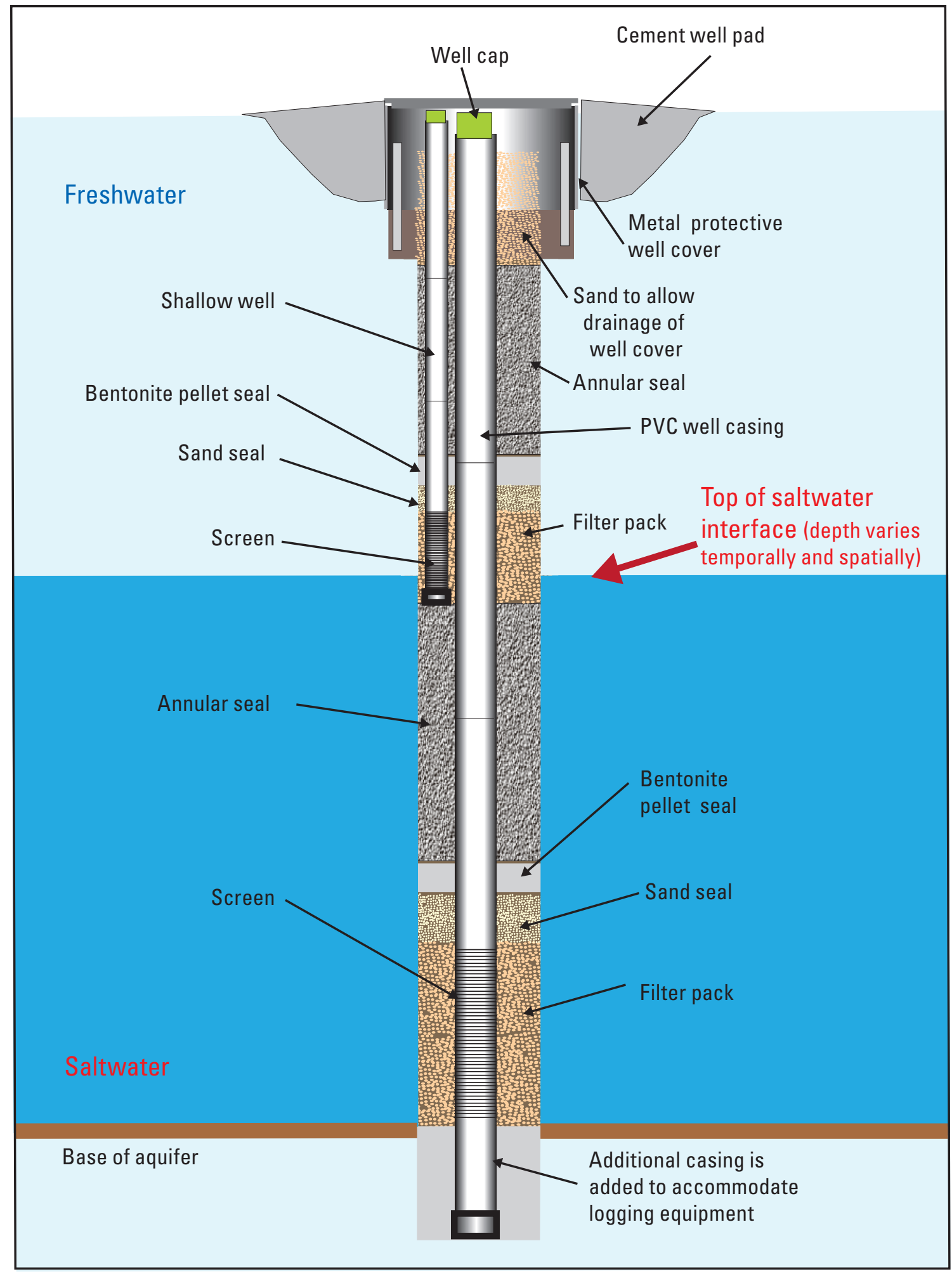

Figure 3. Diagram of short-screened interval monitoring wells used for water sampling and collection of time series electromagnetic-induction log datasets. [PVC, polyvinyl chloride] 
The USACE and the International Analytic Group (IAG) monitored seven long-screened interval wells to aid in the evaluation of changes that might be related to installation of the seepage barrier. Five of these long-screened wells are located near the short-screened wells monitored by the USGS (fig. 1 and table 2). These five long-screened wells are 160 to $200 \mathrm{ft}$ deep, and have open intervals ranging from 145 to $185 \mathrm{ft}$ in length. Data from these five wells were used to help evaluate differences between water samples obtained from long-screened wells and the water samples and TSEMIL datasets collected in short-screened wells.

TSEMIL datasets, collected by the USGS, consist of a series of electromagnetic-induction (EMI) logs collected through time. Generally the individual EMI logs of the TSEMIL datasets were collected on a monthly or bimonthly basis for this project. EMI logs measure the bulk conductivity of the aquifer, which is a function of the electrical conductivity of the pore water and the characteristics of the rock matrix, including pore structure, shape, and total porosity. Changes in the bulk conductivity can be detected, even through PVC well casings. TSEMIL datasets depict temporal changes in the conductivity of the water in the aquifer, because the characteristics of the rock matrix generally do not change appreciably during the period of monitoring. Individual EMI logs in the TSEMIL dataset are color coded by collection date in the red, orange, yellow, green, blue, indigo, and violet color sequence. The most recent log is colored black. If all of the individual EMI logs plot directly on top of each other, the water conductivity is not changing. A monotonic increase or decrease in water conductivity through time results in a set of curves or curve segments that follow the above mentioned color sequence. TSEMIL datasets were processed as described in Prinos and others (2014). EMI logs collected between August 2012 and April 2013 showed an increase in measurement noise, relative to preceding and subsequent logs. A 5-point moving average was used to smooth the data in those logs where the noise obscured the changes in bulk conductivity.

Prinos and others (2014) established the relation between bulk conductivity from EMI logs and chloride concentrations of water samples collected in the Biscayne aquifer of MiamiDade County, Florida, which showed that parts of the aquifer containing saltwater with 1,000 milligrams $(\mathrm{mg} / \mathrm{L})$ of chloride

Table 2. Design of long-screened monitoring wells, and depth and date of completion of seepage barrier.

[--, no information; ft, foot; LS, land surface; NGVD 29, National Geodetic Vertical Datum of 1929]

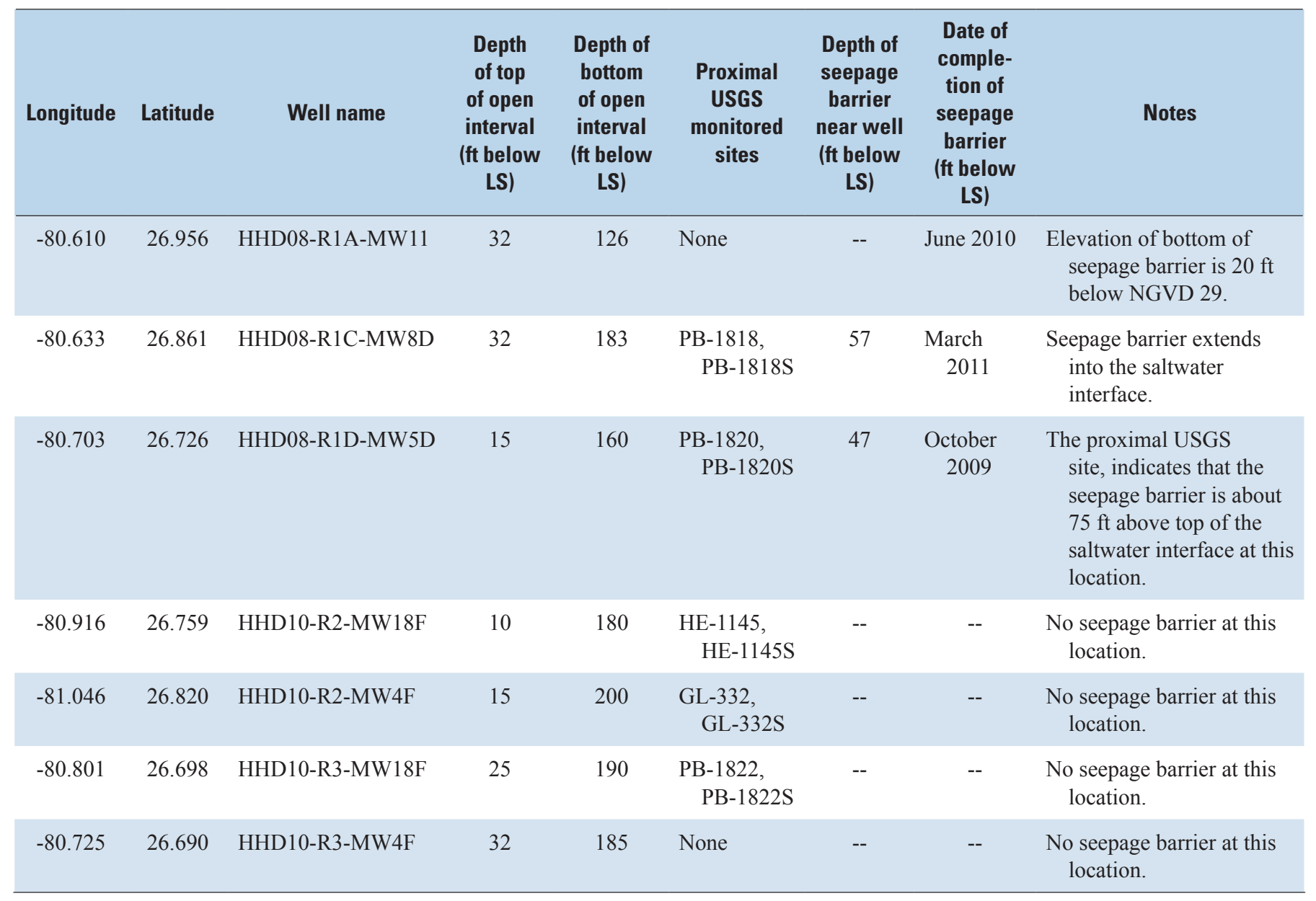


or greater have formation conductivity values of about 100 millisiemens per meter $(\mathrm{mS} / \mathrm{m})$ or greater (equivalent to a bulk resistivity of about $10 \mathrm{ohm}-\mathrm{m}$ or less). For the purposes of this study, the shallowest depth at which an EMI log indicated a bulk conductivity of $100 \mathrm{mS} / \mathrm{m}$ was generally considered to be the top of the saltwater interface, except where EMI logs may have been affected by variations in water saturation of the unsaturated zone, or where layers of conductive clay resulted in greater than normal bulk conductivity.

Water samples were collected by the USGS from the shallow and deep short-screened interval monitoring wells to evaluate the chloride concentration and specific conductance of water in the aquifer. Wells were sampled, monthly or bimonthly, to evaluate temporal changes in salinity. Water samples were collected from the wells, following the removal of 3 to 5 well volumes of water, to ensure that the samples were representative of water in the aquifer rather than in the well bore. Samples were not filtered prior to analysis. The chloride concentration of water samples was determined by the USGS using a Seal Analytical AQ1 discrete analyzer. Specific conductance was measured using a Mettler Toledo Seven Easy conductivity meter.

IAG collected water samples from the long-screened interval wells at depth intervals of about 5 to $10 \mathrm{ft}$ using straddle packers to isolate each sampling interval. Each packer was $3 \mathrm{ft}$ long, and a bladder pump located between the packers was used to collect the water samples. A YSI multi-parameter meter was used to measure field water-quality parameters. Water samples were analyzed by the TestAmerica laboratory. Quality assurance samples including method blanks were also collected. Method blanks were used to determine if the equipment cleaning procedures designed to prevent cross contamination between wells had successfully removed all traces of the analyte for which sampling is conducted. Detections of the analyte in method blanks are noted in the figures and appendixes of this report.

\section{Results}

Monitoring results from locations where the seepage barrier was installed can be compared to those from locations without it to understand whether apparent changes in aquifer salinity are caused by natural variation, ambiguity in results, or the barrier. Sample results from the shallow well of each short-screened well cluster, for example, generally showed increases in chloride concentration where the seepage barrier was installed to a depth near or below that of the saltwater interface (fig. 4D-G; table 1), and there was little or no change where the seepage barrier was not installed (fig. $4 A, B$, and $J$; table 1 ) or where the seepage barrier was well above the saltwater interface (fig. $4 C, H$, and $I$; table 1 ). Monitoring results at locations without the seepage barrier and those with it are discussed in greater detail in the "Locations Without a Seepage Barrier" and "Locations With a Seepage Barrier" sections of this report.
Sample results from five of the long-screened wells monitored by IAG are compared to those of water samples and TSEMIL datasets collected from the collocated shortscreened well clusters in the "Comparison of Information From Short-Screened and Long-Screened Wells" section of this report. IAG sample results were provided by the USACE (appendix 1; Mark Shafer, U.S. Army Corps of Engineers, written commun., April 25, 2011). Long-screened wells, like those monitored by IAG during this study, are commonly used to monitor salinity in Florida, as well as in other states and countries. Well-bore flow under ambient conditions, however, has been shown to alter the distribution of salinity in the well relative to that in the aquifer (Reilly and others, 1989; Johnson and others, 2002; Shapiro, 2002; Oki and Presley, 2008; Runkel and others, 2008; and Shalev and others, 2009). Information collected from the short-screened and long-screened wells can be compared to evaluate any differences that may have resulted from flow within the well bore.

TSEMIL datasets from most monitoring wells indicated temporal changes in bulk conductivity near the water table. The maximum depth of the water table in well PB-1821, for example, was $10.42 \mathrm{ft}$ below land surface (fig. 5). The induction logging probe is $5.2 \mathrm{ft}$ long, and in this instance, would not be fully submerged until it reached a depth of $15.6 \mathrm{ft}$. Bulk conductivity values in the TSEMIL dataset for the interval 0 to $16 \mathrm{ft}$ could possibly be influenced by temporal variations in the water saturation in the unsaturated zone above the depth of the water table and by incomplete submergence of the probe. Although the delineation of these changes was not the focus of this study, the maximum water table depth and depth at which the probe is fully submerged are depicted on some of the graphs of the TSEMIL datasets for informational purposes.

\section{Locations Without a Seepage Barrier}

Water sample results and TSEMIL datasets generally did not indicate large changes in bulk conductivity or salinity near the depth of the saltwater interface at locations where the seepage barrier had not been installed. At the time of this study, reaches 2 and 3 of the barrier had not been installed near well clusters GL-332S/GL-332, HE-1145S/HE-1145, and $\mathrm{PB}-1822 \mathrm{~S} / \mathrm{PB}-1822$ (fig. 1). The monitoring-well cluster PB-1821/PB-1821S is located $1,150 \mathrm{ft}$ south of the end of reach $1 \mathrm{D}$ of the seepage barrier on Torry Island, $940 \mathrm{ft}$ west of the HHD (table 1); this is the only well cluster on the Lake Okeechobee side of the HHD. Throughout most of the depth interval of well PB-1821, except near the water table, the 10 individual logs of the TSEMIL dataset plot directly or almost directly on top of each other, which indicates little or no change in bulk conductivity through time (fig. 5). Changes of only 1 to $5 \mathrm{mS} / \mathrm{m}$ in the depth intervals 14 to $28 \mathrm{ft}, 71$ to $91 \mathrm{ft}$, and 109 to $134 \mathrm{ft}$ were observed. The depth of the top of the saltwater interface increased by $0.8 \mathrm{ft}$ during the study. The open interval of the shallow well PB-1821S is about $7 \mathrm{ft}$ above the saltwater interface (fig. 5; table 1). The chloride 

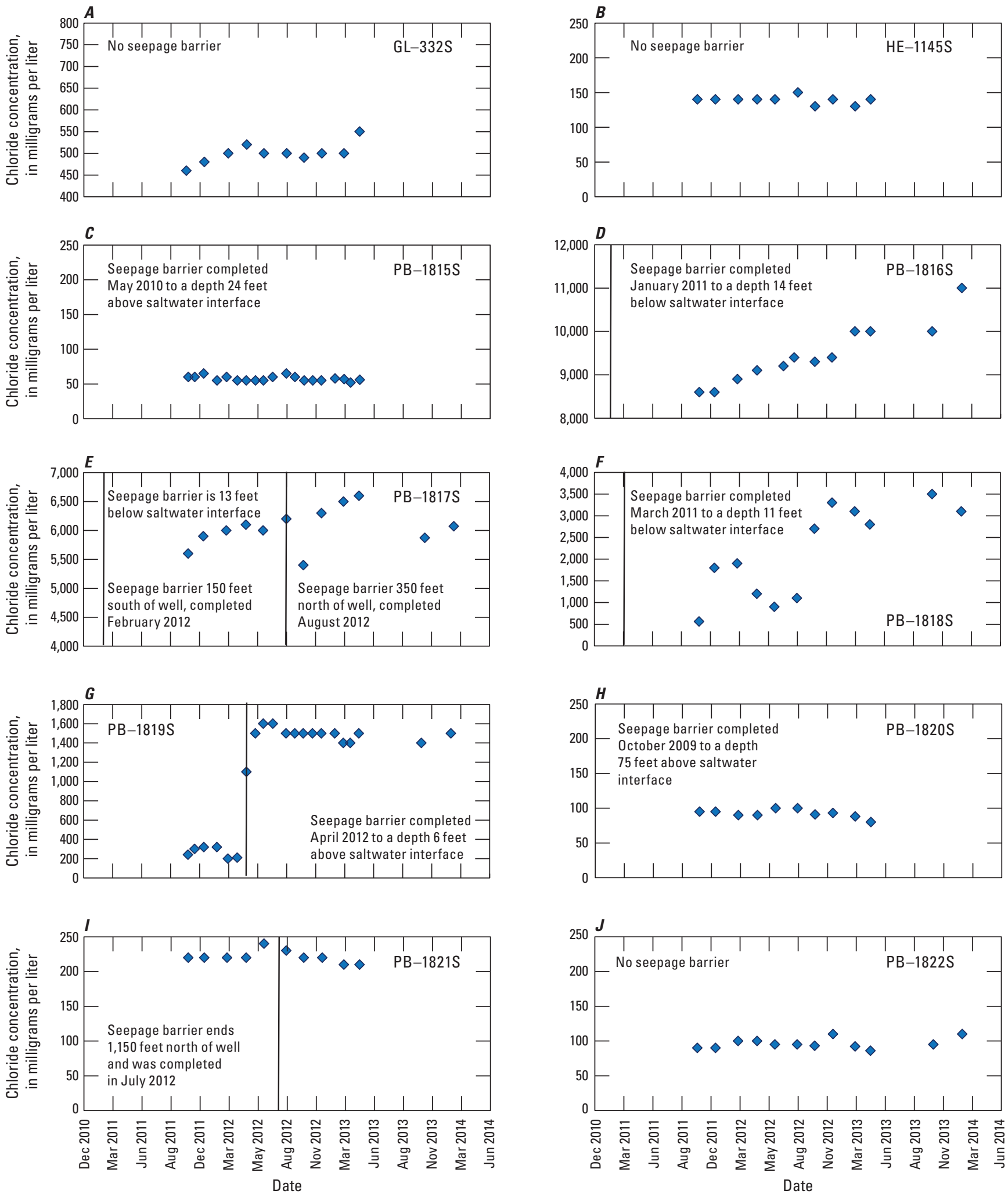

Figure 4. Chloride concentration of water samples from shallow, short-screened monitoring wells near Lake Okeechobee, Florida. (See fig. 1 for well locations.) Vertical lines, if present, indicate the date of installation of the seepage barrier. 


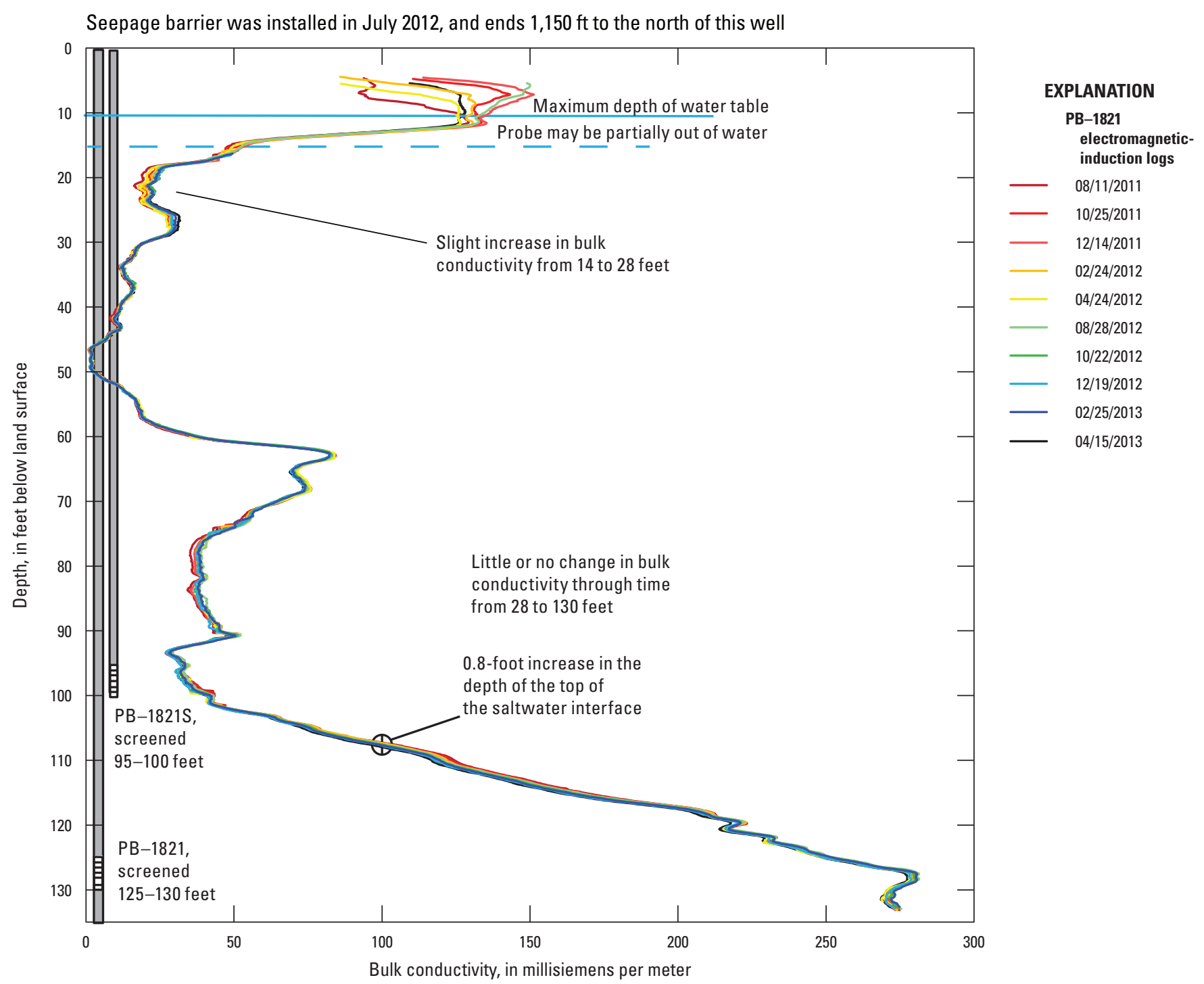

Figure 5. Time series electromagnetic-induction log (TSEMIL) dataset from monitoring well PB-1821, generally showing only minor temporal changes in the bulk conductivity of the aquifer. Circle shows depth of the top of the saltwater interface inferred from TSEMIL dataset, as a bulk conductivity of $100 \mathrm{mS} / \mathrm{m}$. [ft, foot; mg/L milligrams per liter; \%, percent; $\mathrm{mS} / \mathrm{m}$, millisiemens per meter]

concentration of water samples from PB-1821S confirm that only minor changes in salinity have occurred at its open interval. Chloride concentrations of samples from this well ranged from 210 to $240 \mathrm{mg} / \mathrm{L}$ during the study (fig. $4 I$ ). The deep well, PB-1821, is open to the aquifer about $18 \mathrm{ft}$ below the top of the saltwater interface. Water samples from this well indicate that the chloride concentration has been fairly constant. Nine of the 11 water samples from PB-1821 have a chloride concentration of $3,900 \mathrm{mg} / \mathrm{L}$ (appendix 2).

The TSEMIL datasets from wells GL-332, HE-1145, and PB-1822 indicated little or no change in the depth of the saltwater interface during this study (figs. 6A, 7A, and $8 A$ ). The TSEMIL dataset from well GL-332 (fig. $6 A$ ) indicated variations in bulk conductivity through time in the depth interval 20 to $30 \mathrm{ft}$. These variations are almost entirely above a greenish clay and silt layer that extends from about 28 to
$44 \mathrm{ft}$ below land surface. Clay typically has a higher electrical conductivity than sand or limestone (U.S. Environmental Protection Agency, 2014a). This clay and silt layer is indicated within the depth interval 32 to $42 \mathrm{ft}$ of the TSEMIL dataset by bulk conductivities that are up to $130 \mathrm{mS} / \mathrm{m}$ and relatively constant through time. The saltwater interface, inferred from the TSEMIL dataset, begins below this clay and silt layer, at a depth of $62 \mathrm{ft}$. Just above the saltwater interface, there was a minor 6-mS/m increase in bulk conductivity through time. Temporal changes in bulk conductivity near the saltwater interface are probably not related to temporal changes in the depth interval 20 to $30 \mathrm{ft}$ because the clay unit between them likely restricts vertical flow in the aquifer. There was little or no temporal change in bulk conductivity in the interval 60 to $108 \mathrm{ft}$ and a minor increase in the interval 108 to $129 \mathrm{ft}$. The chloride concentration of water samples from the shallow 


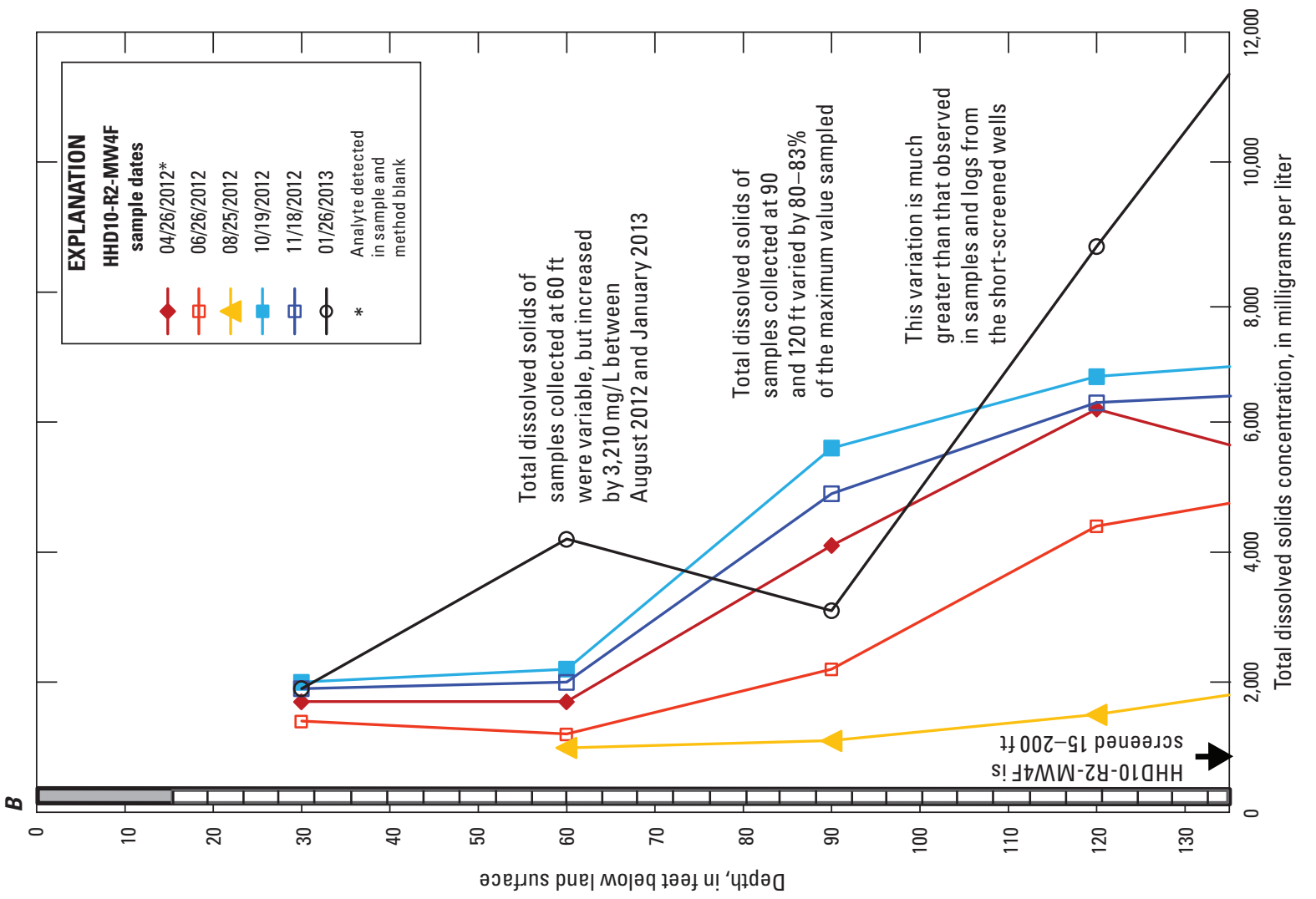

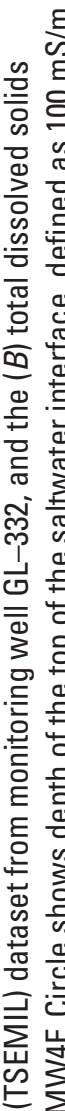

으순

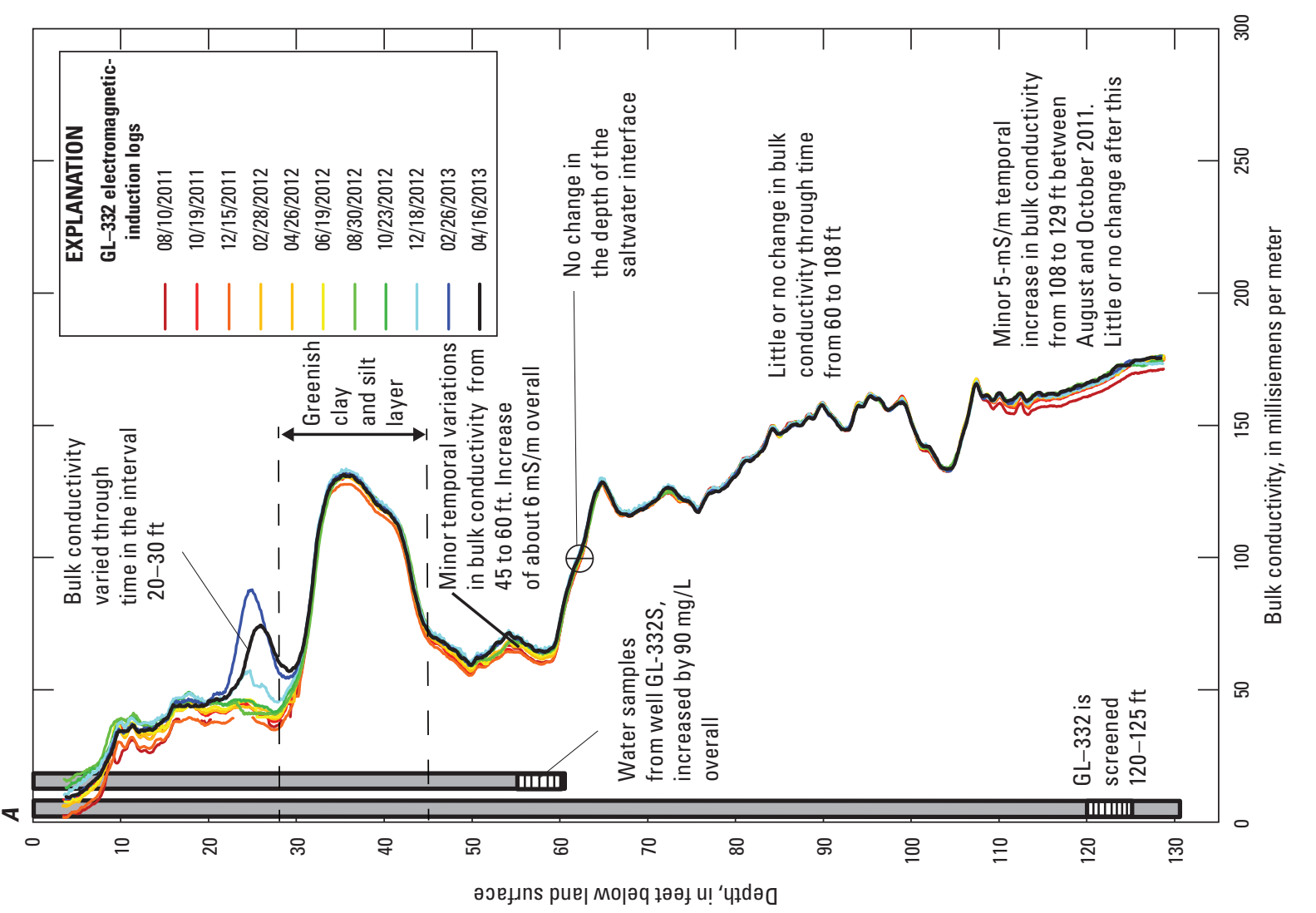

응응

둥

긍 종

i $\overline{\overline{0}}$

3

등 잏

항

흘

헐 을

틈

$\mathscr{\&}$

잉

()

Е

उ这

흘

索

ธ 产

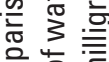

है

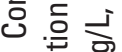

0

잉

高方 
well, GL-332S, screened from 55 to $60 \mathrm{ft}$, varied through time but increased by $90 \mathrm{mg} / \mathrm{L}$ overall during the study (fig. $4 A$ ). The drawdown induced by well sampling in well GL-332 was so great that a sample could not readily be collected. The TSEMIL dataset from well HE-1145 indicated minor temporal variations in bulk conductivity above the saltwater interface but no change in the depth of the interface (fig. $7 A$ ). During the study, the chloride concentration of samples from well HE-1145S only varied by $20 \mathrm{mg} / \mathrm{L}$ (fig. $4 B$ ). The TSEMIL dataset from well PB-1822 indicated a minor $14-\mathrm{mS} / \mathrm{m}$ variation in bulk conductivity in the depth interval 55 to $60 \mathrm{ft}$, which is a few feet above the top of the saltwater interface (fig. 8A). Water samples from the shallow well, PB-1822S, screened at the same depth as this variation in bulk conductivity, indicated that chloride concentration at this depth varied by about $24 \mathrm{mg} / \mathrm{L}$ (fig. $4 J$ ). The chloride concentration of water samples from the deep well, PB-1822, only varied by 10 percent during the project (appendix 2).

Monitoring-well cluster PB-1817/PB-1817S is farther away from the HHD than the other wells. The cluster is located adjacent to the West Palm Beach Canal and 1,550 ft southeast of the centerline of the HHD, and there is a $500-\mathrm{ft}$ gap in the seepage barrier at this location (table 1). The seepage barrier south of this location was completed in February 2011, and the barrier to the north was completed in August 2012. The chloride concentration of samples from well PB-1817S increased after the completion of the seepage barrier to the south, but decreased briefly after completion of the northern seepage barrier before resuming an overall increase of $800 \mathrm{mg} / \mathrm{L}$, relative to the initial chloride concentration (fig. $4 E$ ). In the depth interval 50 to $70 \mathrm{ft}$, near the depth of the bottom of the seepage barrier, the bulk conductivity of EMI logs increased, but the depth to the top of the saltwater interface only oscillated up and down slightly through time (fig. 9). Generally, bulk conductivity increased overall in the depth interval 81 to $110 \mathrm{ft}$, but these changes varied through time and with depth.

\section{Locations With a Seepage Barrier}

The TSEMIL datasets from the wells PB-1815, PB-1816, PB-1818, and PB-1819, where the seepage barrier extends near to or below the top of the saltwater interface, indicated changes in the depth and bulk conductivity of the interface (figs. 10; 11; 12A, $C, D$; and 13). The TSEMIL datasets from these wells indicated (1) decreases in the depth of the saltwater interface, through time, of 2.4 to $18.7 \mathrm{ft}$;

(2) increases in bulk conductivity through time from depths of 0 to $29 \mathrm{ft}$ above to 0 to $18 \mathrm{ft}$ below the bottom of the seepage barrier; and (3) decreases in bulk conductivity, through time, in the aquifer, beginning at depths of 11 to $18 \mathrm{ft}$ below the bottom of the seepage barrier and extending to depths of 34 to $73 \mathrm{ft}$ below the bottom of the seepage barrier.

The TSEMIL dataset from well PB-1815 indicated temporal changes in bulk conductivity that corresponded closely with the depth of the bottom of the seepage barrier, $46 \mathrm{ft}$, which was completed in May 2010 (fig.10; table 1). This dataset consists of 21 EMI logs that were collected on a monthly basis. Between August 2011, when the first log was collected, and April 2013, the bulk conductivity of the aquifer increased by as much as $25 \mathrm{mS} / \mathrm{m}$ in the depth interval 46 to $74 \mathrm{ft}$, and the depth of the saltwater interface decreased by $2.4 \mathrm{ft}$. Bulk conductivity decreased in the depth interval 74 to $80 \mathrm{ft}$. Bulk conductivity had initially increased in the depth interval 64 to $74 \mathrm{ft}$ but started decreasing in September 2012. The saltwater interface, therefore, may be gradually beginning to return to its initial depth. Below a depth of about $87 \mathrm{ft}$, the TSEMIL dataset indicated little or no change in bulk conductivity. Analyses of water samples at well PB-1815S did not indicate an increase in chloride concentration because the bottom of the well's intake was 25.4 to $23 \mathrm{ft}$ above the saltwater interface during this study (fig. 10). All but one of the water samples from the deep well, PB-1815, have a chloride concentration of 13,000 mg/L (appendix 2).

Most of the reaches of the seepage barrier (fig. 1) were completed before monitoring began at the well clusters. The seepage barrier near monitoring-well cluster PB-1816/ PB-1816S, for example, was completed in January 2011, about 8 months before monitoring began. In the depth interval 36 to $68 \mathrm{ft}$, which brackets the depth of the seepage barrier, the TSEMIL dataset from PB-1816 indicated increasing bulk conductivity during August 2011-January 2014 (fig. 11); the depth of the saltwater interface decreased $5.5 \mathrm{ft}$ during this period. The chloride concentration of water samples collected from well PB1816S increased from 8,600 to $11,000 \mathrm{mg} / \mathrm{L}$ between October 26, 2011, and January 30, 2014 (fig. 4D). Beginning about $11 \mathrm{ft}$ below the bottom of the seepage barrier, bulk conductivity in the depth interval 68 to $104 \mathrm{ft}$ decreased, and there was little or no change in bulk conductivity below a depth of $106 \mathrm{ft}$. The chloride concentration of samples from the deep well, PB-1816, varied between 14,000 and $16,000 \mathrm{mg} / \mathrm{L}$ (appendix 2).

The TSEMIL dataset collected in monitoring well PB-1818 indicated (1) a temporal decrease in the depth of the saltwater interface of $3.7 \mathrm{ft}$ during the study period; (2) a temporal increase in bulk conductivity from about $29 \mathrm{ft}$ above to $8 \mathrm{ft}$ below the bottom of the seepage barrier; (3) a temporal decrease in bulk conductivity from 18 to $49 \mathrm{ft}$ below the bottom of the seepage barrier (fig. 12D); and (4) a temporal increase in bulk conductivity from about 70 to $77 \mathrm{ft}$ below the bottom of the seepage barrier, which corresponds to the depth interval 127 to $134 \mathrm{ft}$ (fig. 12A). Water samples collected from the deep well, PB-1818, which is open from 135 to $140 \mathrm{ft}$ (table 1), indicated a variation in chloride concentration of 2,000 $\mathrm{mg} / \mathrm{L}$ (appendix 2). Water samples from the shallow well, PB-1818S, indicated an increase in chloride concentration of 2,500 mg/L (fig. 4F).

Monitoring-well cluster PB-1819/PB-1819S was the only cluster monitored before the seepage barrier was completed in its vicinity. Monitoring at this cluster began in August 2011, 

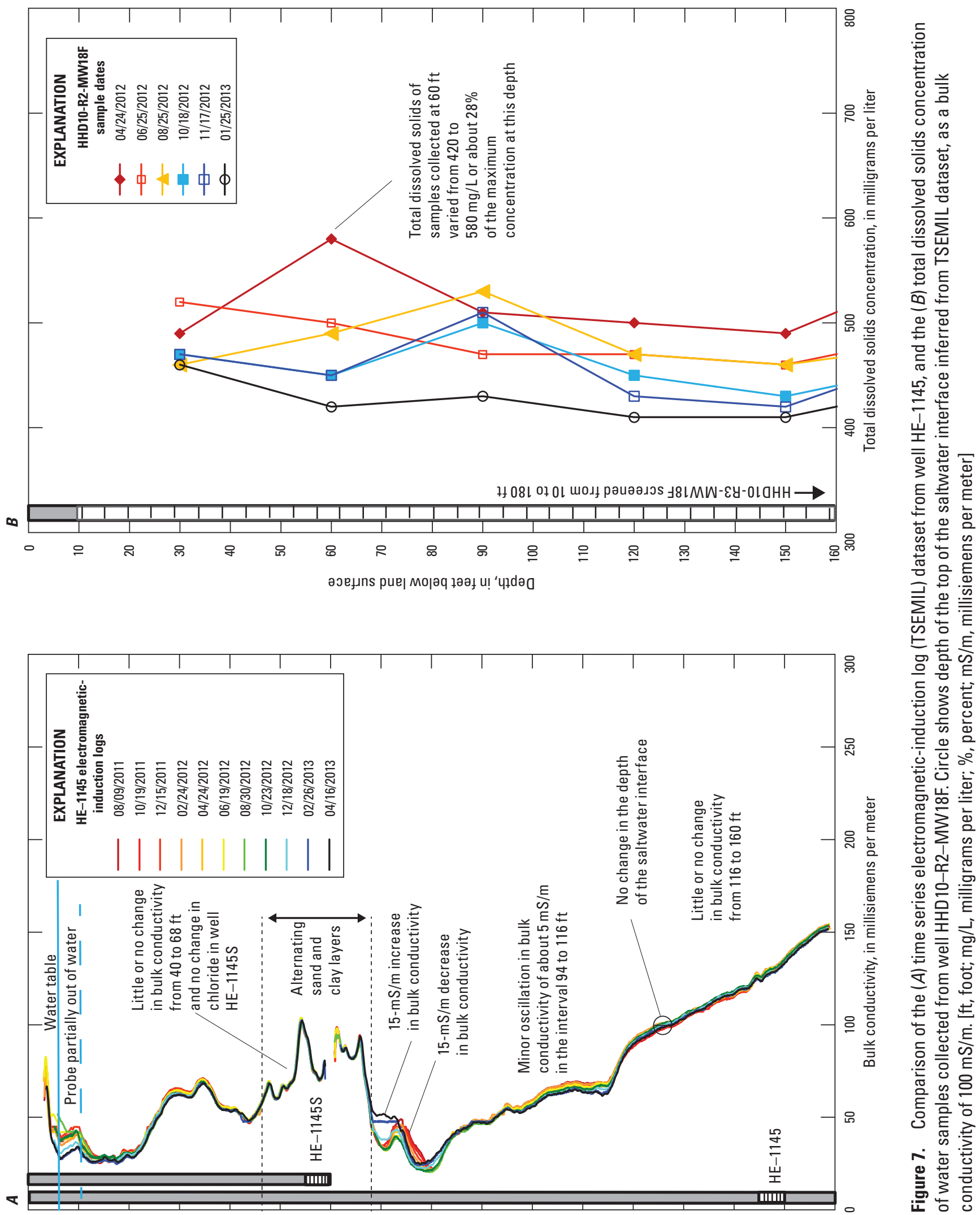


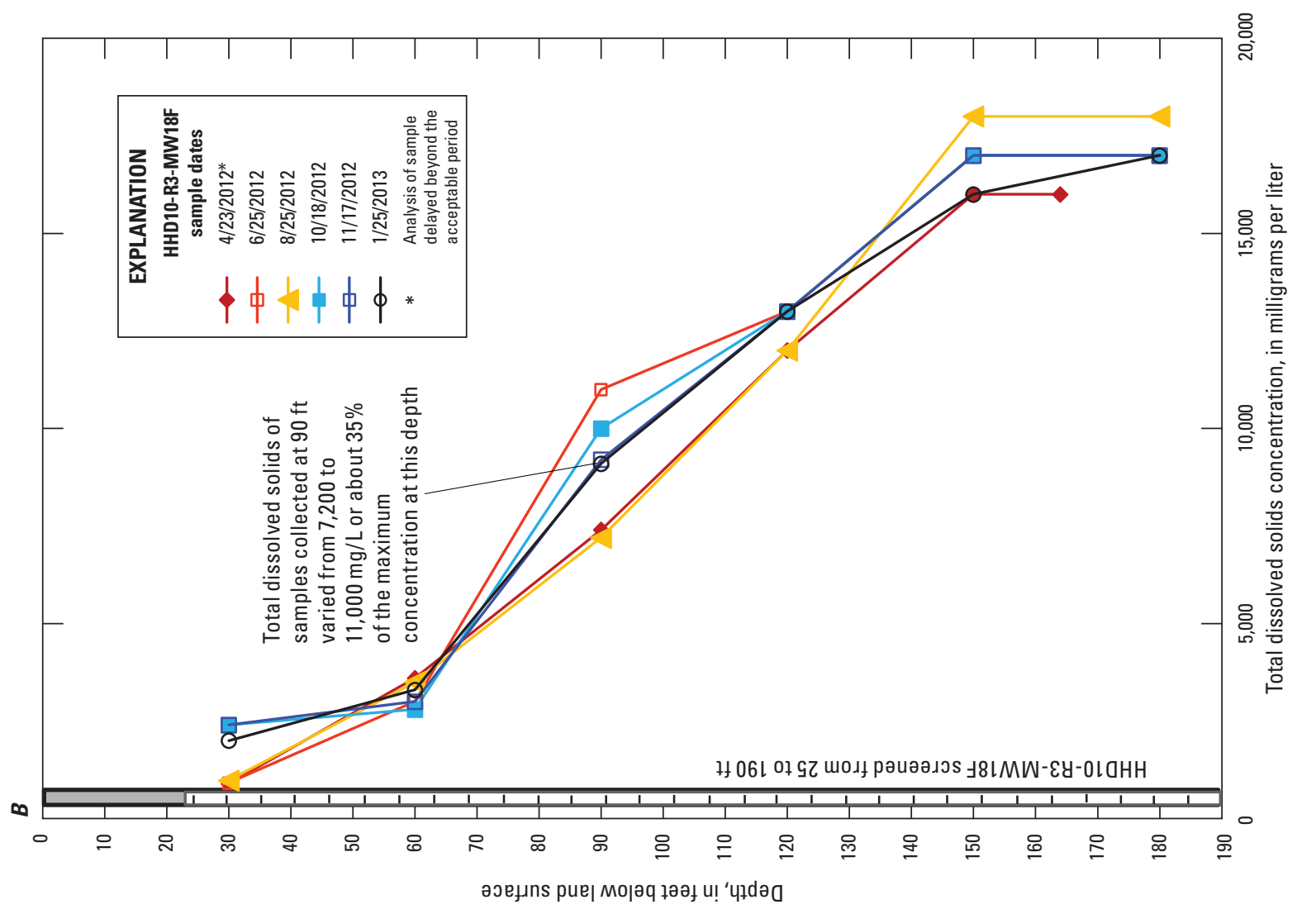

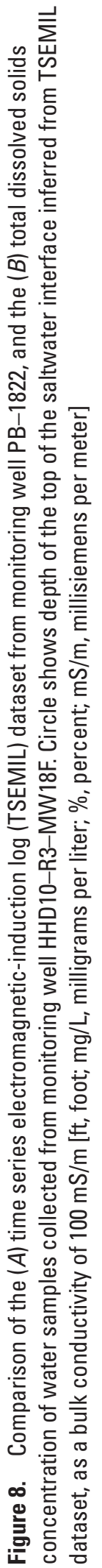




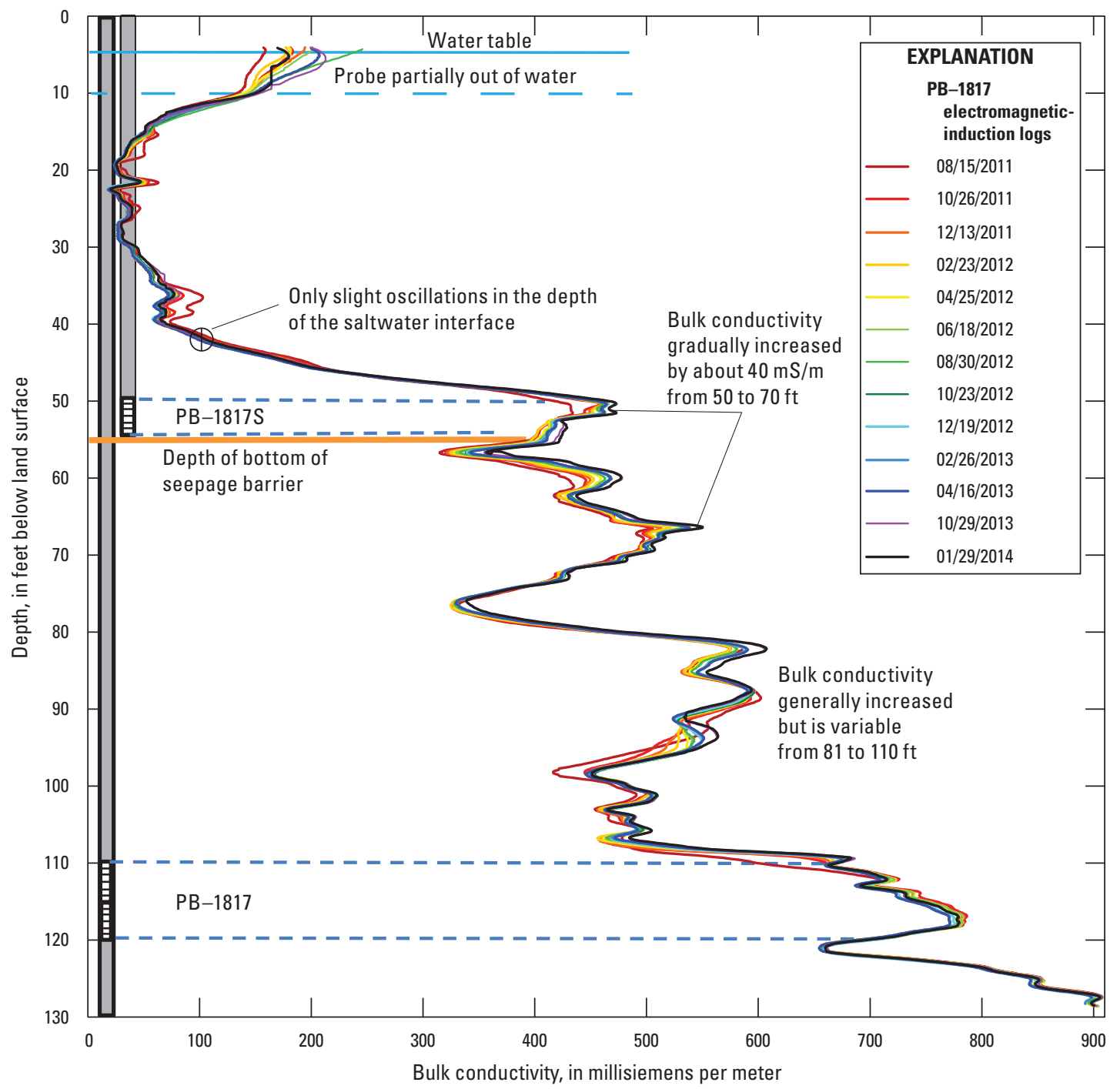

Figure 9. Time series electromagnetic-induction log dataset from monitoring well PB-1817 showing changes in the bulk conductivity of the aquifer. Circle shows depth of the top of the saltwater interface inferred from TSEMIL dataset, as a bulk conductivity of $100 \mathrm{mS} / \mathrm{m}$. [ft, foot; $\mathrm{mS} / \mathrm{m}$, millisiemens per meter]

8 months before the seepage barrier was completed. The TSEMIL dataset from well PB-1819 indicated that prior to completion of the seepage barrier, there was little or no change in the bulk conductivity of aquifer materials. The first EMI log collected after the seepage barrier was completed in April 2012 indicated an increase in bulk conductivity through time in the depth interval 50 to $60 \mathrm{ft}$, near the depth of the bottom of the seepage barrier (fig. 13). Subsequent EMI logs indicated an increase of as much as $98-\mathrm{mS} / \mathrm{m}$ in bulk conductivity from $15 \mathrm{ft}$ above to $8 \mathrm{ft}$ below the bottom of the seepage barrier, decreases in bulk conductivity from 11 to $73 \mathrm{ft}$ below the bottom of the seepage barrier, and a decrease of $18.7 \mathrm{ft}$ in the depth of the saltwater interface. After the seepage barrier was completed, the chloride concentration of the water samples from the shallow well, PB-1819S, increased from 210 to 1,600 mg/L between March 28, 2012, and June 18, 2012 (fig. $4 G$ ). The chloride concentration of water samples from the deep well, PB-1819, varied between 5,600 and 6,000 mg/L (appendix 2).

A seepage barrier was installed near monitoring well PB-1820 in October 2009. The bottom of the seepage barrier is $75 \mathrm{ft}$ above the top of the saltwater interface at this location (fig. 14). The chloride concentration of water samples from well PB-1820S, which is about $27 \mathrm{ft}$ above the top of the saltwater interface, only varied by $20 \mathrm{mg} / \mathrm{L}$ (fig. $4 H$ ). The TSEMIL dataset indicated an increase of $0.5 \mathrm{ft}$ in the depth of the saltwater interface at this location and as much as a $10-\mathrm{mS} / \mathrm{m}$ decrease in bulk conductivity in the depth interval 108 to $121 \mathrm{ft}$, which is just above the interface. Between October 2011 and April 2013, the chloride concentration of samples from the wells PB-1820 decreased from 1,900 to $1,800 \mathrm{mg} / \mathrm{L}$ (appendix 2). Bulk conductivity increased as much as $18 \mathrm{mS} / \mathrm{m}$ from 13 to $32 \mathrm{ft}$ above the top of the seepage barrier. 


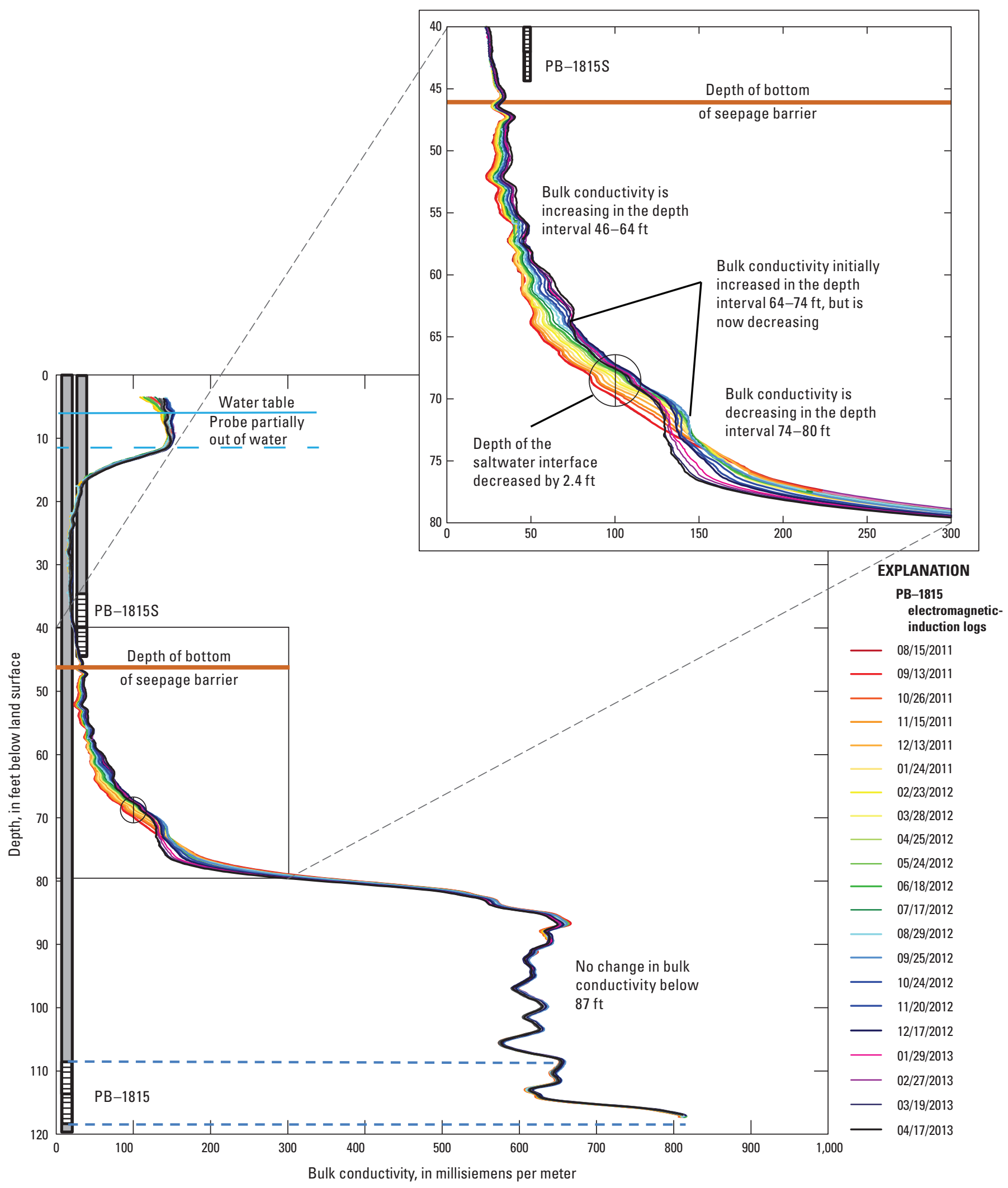

Figure 10. Time series electromagnetic-induction log (TSEMIL) dataset from monitoring well PB-1815 showing changes in the bulk conductivity of the aquifer. Circle shows depth of the top of the saltwater interface inferred from TSEMIL dataset, as a bulk conductivity of $100 \mathrm{mS} / \mathrm{m}$. [ft, foot; $\mathrm{mS} / \mathrm{m}$, millisiemens per meter] 


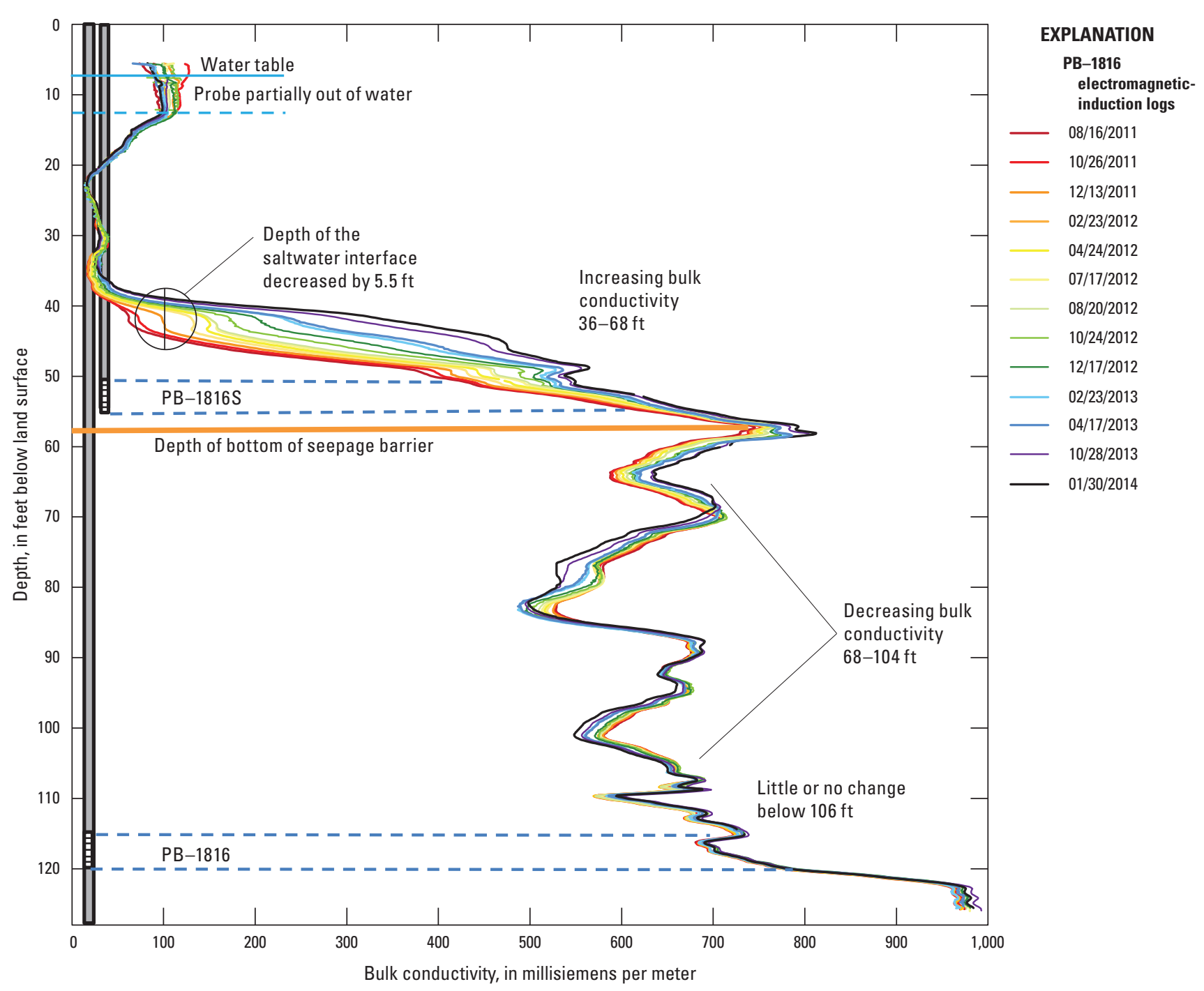

Figure 11. Time series electromagnetic-induction log (TSEMIL) dataset from monitoring well PB-1816 showing changes in the bulk conductivity of the aquifer. Circle shows depth of the top of the saltwater interface inferred from TSEMIL dataset, as a bulk conductivity of $100 \mathrm{mS} / \mathrm{m}$. [ft, foot; $\mathrm{mS} / \mathrm{m}$, millisiemens per meter]

\section{Comparison of Information From Short-Screened and Long-Screened Wells}

The results of monitoring of the long-screened interval wells were probably affected by flow within the well bore and were frequently too temporally variable to be used to evaluate changes in aquifer salinity that could be related to installation of the seepage barrier. The concentration of total dissolved solids (TDS) of water samples collected from the long-screened monitoring wells HHD08-

R1D-MW5D (fig. 15), HHD10-R2-MW18F (fig. 7B), HHD10-R3-MW18F (fig. 8B), and HHD10-R2-MW4F (fig. $6 B$ ) varied over time to a greater extent than the results of water sampling and electromagnetic-induction logging in the respective, collocated, short-screened well clusters, PB-1820S/PB-1820 (figs. $4 H$ and 14), HE-1145S/HE-1145 (figs. $4 B$ and $7 A$ ), $\mathrm{PB}-1822 \mathrm{~S} / \mathrm{PB}-1822$ (figs. $4 J$ and $8 A$ ), and
GL-332S/GL-332 (figs. $4 A$ and $6 A$ ). The TDS and chloride concentrations of water samples from a depth of $130 \mathrm{ft}$ in well HHD08-R1D-MW5D, for example, varied by 34 and 43 percent, respectively, of the maximum concentrations sampled at this depth (appendix 1; fig. 15). The chloride concentration of water samples from well PB-1820, which is collocated with well HHD08-R1D-MW5D and open to the aquifer in the depth interval 125 to $130 \mathrm{ft}$, decreased by only 5 percent, from 1,900 to $1,800 \mathrm{mg} / \mathrm{L}$ (appendix 2). The TSEMIL dataset from well PB-1820 indicated only a slight decrease in bulk conductivity at $130 \mathrm{ft}$ (fig. 14).

The concentrations of TDS and chloride in water samples from well HHD10-R2-MW18F, varied by 28 and 59 percent, respectively, of the maximum sampled at $60 \mathrm{ft}$ (fig. $7 B$ and appendix 1). The chloride concentration of samples from well HHD10-R2-MW18F at a depth of $60 \mathrm{ft}$ ranged from 24 to $59 \mathrm{mg} / \mathrm{L}$, whereas the chloride concentration of water samples 

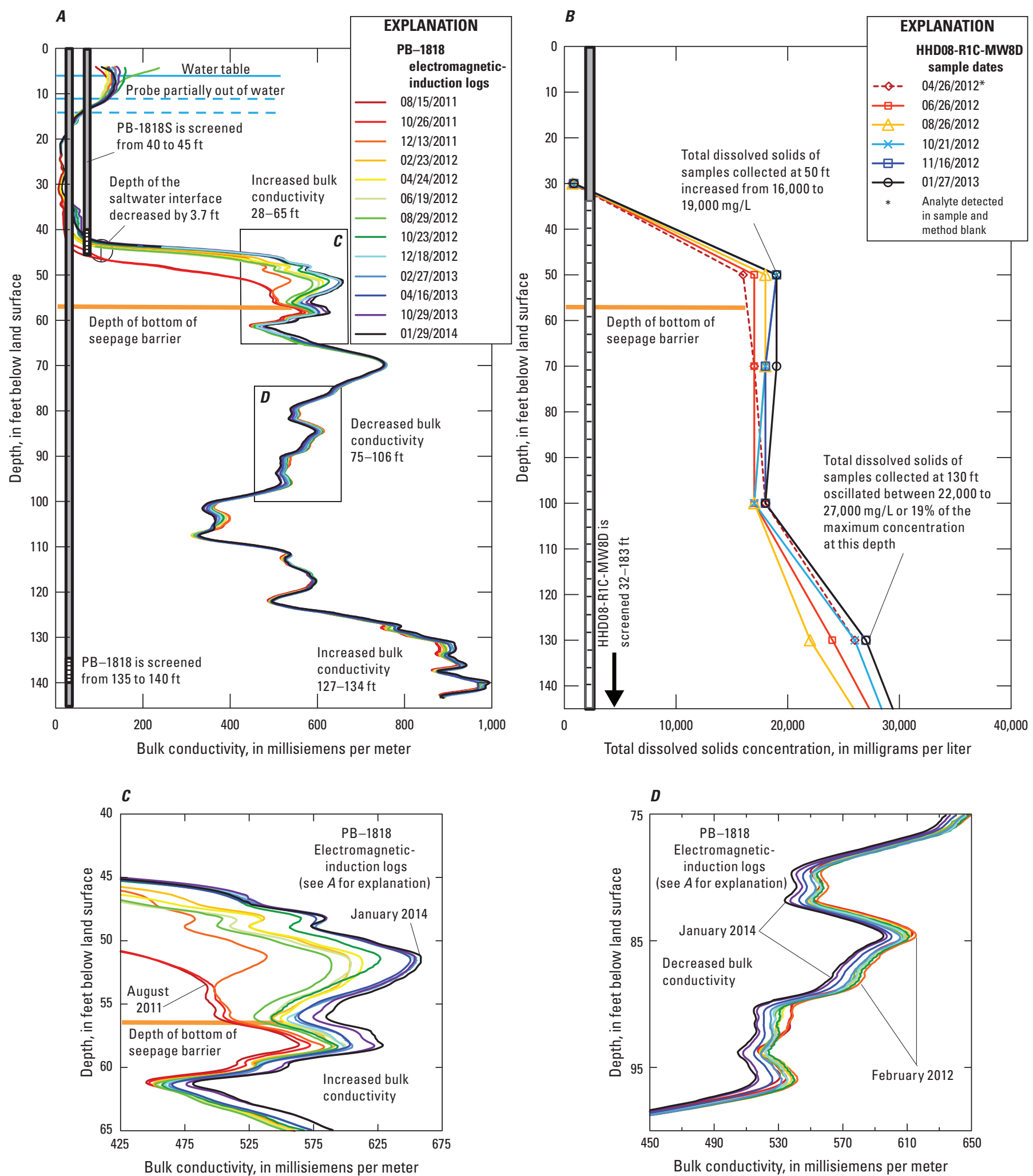

Figure 12. Comparison of the $(A)$ time series electromagnetic-induction log (TSEMIL) dataset from well PB-1818, and the $(B)$ total dissolved solids concentration of water samples collected from well HHD08-R1C-MW8D, including detailed depictions of the TSEMIL dataset from $(C)$ 40-65 ft, and $(D) 75-100 \mathrm{ft}$. Circle shows depth of the top of the saltwater interface inferred from TSEMIL dataset, as a bulk conductivity of $100 \mathrm{mS} / \mathrm{m}$. [ft, foot; $\mathrm{mg} / \mathrm{L}$ milligrams per liter; \%, percent; $\mathrm{mS} / \mathrm{m}$, millisiemens per meter] 


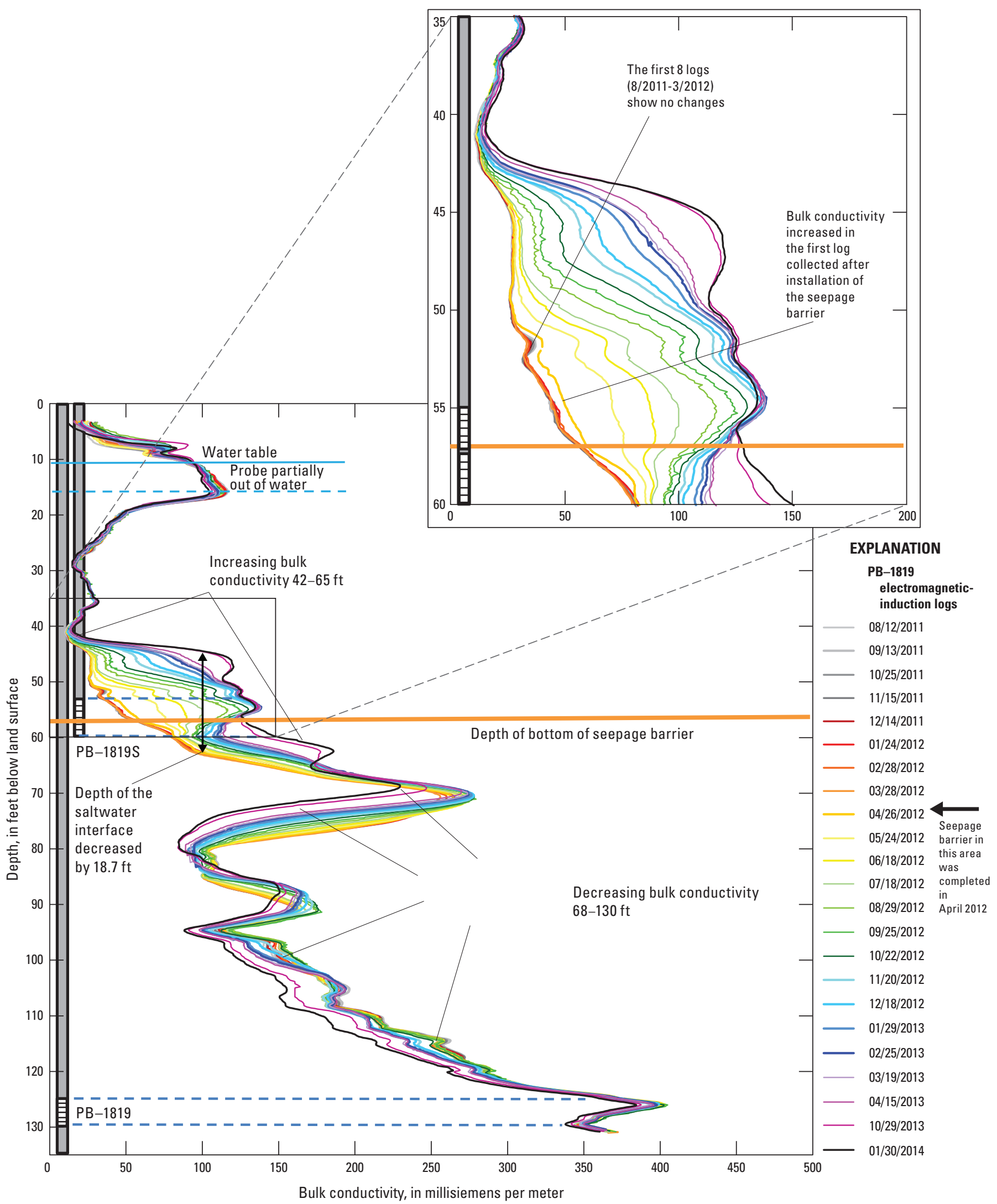

Figure 13. Time series electromagnetic-induction log (TSEMIL) dataset from monitoring well PB-1819 showing changes in the bulk conductivity of the aquifer. Arrow shows change in depth of the top of the saltwater interface inferred from TSEMIL dataset, as a bulk conductivity of $100 \mathrm{mS} / \mathrm{m}$. [ft, foot; $\mathrm{mS} / \mathrm{m}$, millisiemens per meter] 


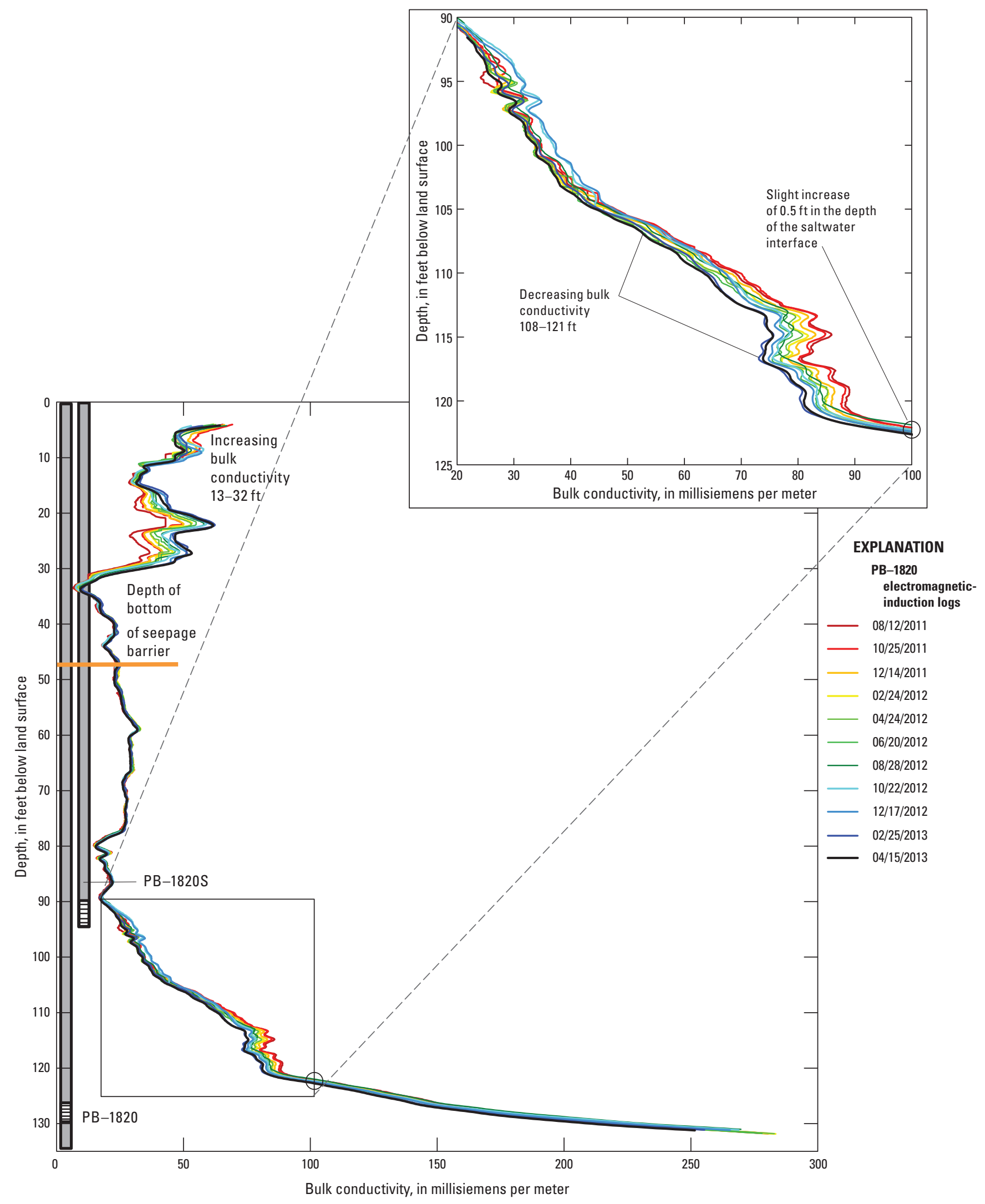

Figure 14. Time series electromagnetic-induction log (TSEMIL) dataset from monitoring well PB-1820 showing temporal changes in the bulk conductivity of the aquifer. Circle shows depth of the top of the saltwater interface inferred from TSEMIL dataset, as a bulk conductivity of $100 \mathrm{mS} / \mathrm{m}$. [ft, foot; $\mathrm{mS} / \mathrm{m}$, millisiemens per meter] 


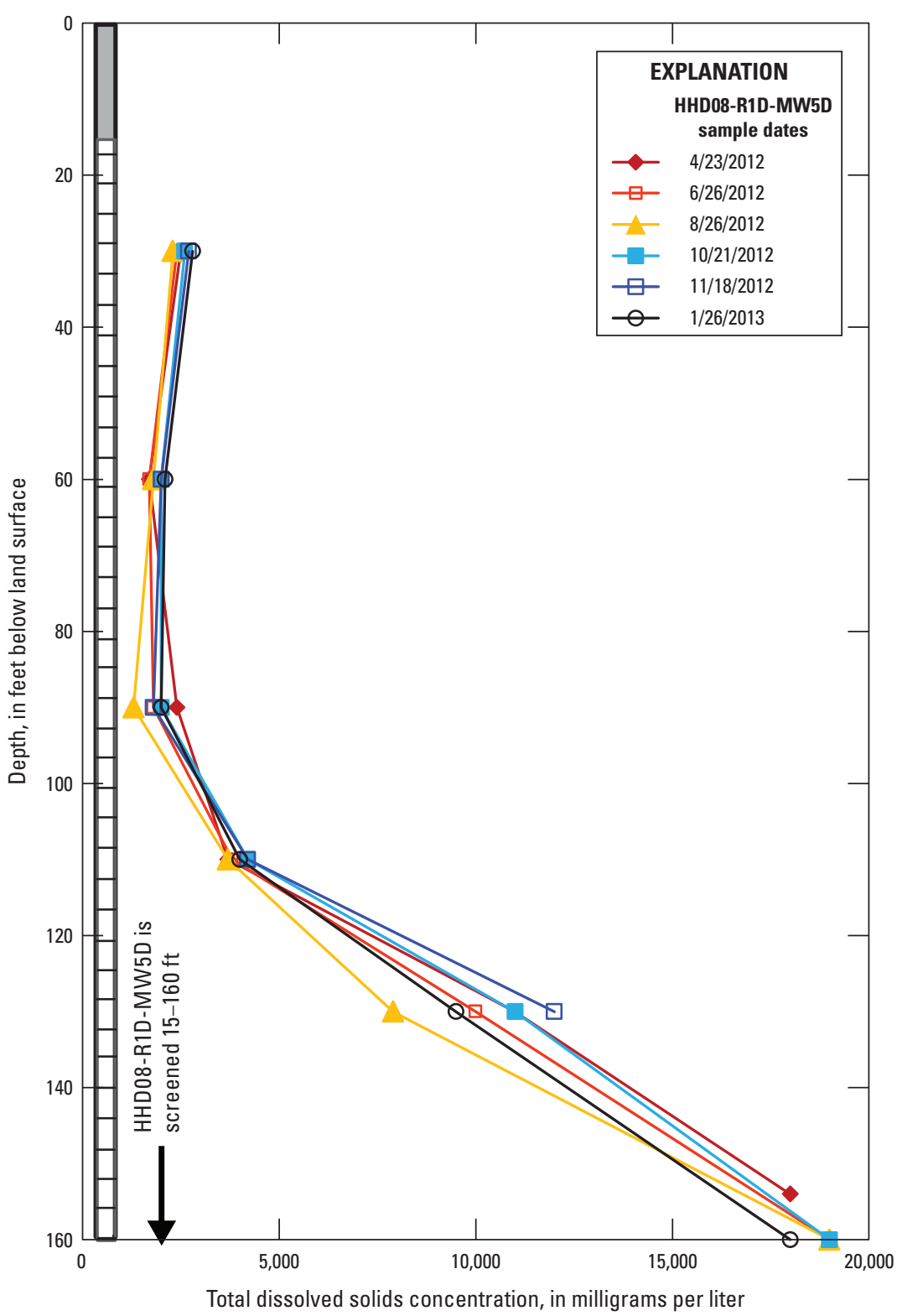

Figure 15. Total dissolved solids concentration of water samples collected from monitoring well HHD08-R1D-MW5D.

from collocated well $\mathrm{HE}-1145 \mathrm{~S}$, which is open to the aquifer from 55 to $60 \mathrm{ft}$, ranged from 130 to $150 \mathrm{mg} / \mathrm{L}$ and varied by only 13 percent of the maximum (fig. $4 B$; appendix 2). Although, some erroneous data in the TSEMIL dataset from well HE-1145, in the depth interval 59 to $62 \mathrm{ft}$, had to be deleted, there was little or no change in the depth interval 55 to $59 \mathrm{ft}$ (fig. $7 A$ ). The concentrations of TDS and chloride in water samples from well HHD10-R2-MW18F varied, respectively, by 19 and 53 percent at $90 \mathrm{ft}, 18$ and 36 percent at $120 \mathrm{ft}$, and 16 and 49 percent at $150 \mathrm{ft}$ (appendix 1), yet the TSEMIL dataset from well HE-1145 indicated little or no change at these depths. Water samples from the deep well HE-1145, open to the aquifer from 145 to $150 \mathrm{ft}$ averaged about $960 \mathrm{mg} / \mathrm{L}$ and varied by $60 \mathrm{mg} / \mathrm{L}$, which is only about 6 percent of the maximum concentration (appendix 2).
The saltwater interface evident in information from well cluster HE-1145/HE-1145S is not evident in the information from well HHD10-R2-MW18F. Water samples from well cluster HE-1145S/HE-1145 indicated chloride concentrations of 130 to $150 \mathrm{mg} / \mathrm{L}$ at 55 to $60 \mathrm{ft}$, and 930 to $990 \mathrm{mg} / \mathrm{L}$ at 145 to $150 \mathrm{ft}$ (appendix 2; table 1). The TSEMIL dataset from well HE-1145 indicated that bulk conductivity gradually increased with depth from 80 to $158 \mathrm{ft}$ (fig. $7 A$ ). The maximum chloride concentration of samples from collocated well HHD10-R2-MW18F was only $71 \mathrm{mg} / \mathrm{L}$ (appendix 1), which is well below the U.S. Environmental Protection Agency secondary drinking water standard of $250 \mathrm{mg} / \mathrm{L}$ (U.S. Environmental Protection Agency, 2014b). The TDS concentration of water samples from well HHD10-R2-MW18F was generally greater at the depths of 60 or $90 \mathrm{ft}$ than at 
150 or $180 \mathrm{ft}$ (appendix 1; fig. $7 B$ ). It is likely that downward freshwater flow within the bore of well HHD10-R2-MW18F diluted samples.

The saltwater interface is evident in the TDS concentration samples collected from well HHD10-R3-MW18F (fig. 8B). The slope of increasing TDS concentration with depth in well HHD10-R3-MW18F is somewhat similar to the slope of increasing bulk conductivity with depth in the collocated well PB-1822 (fig. 8A); however, there is generally greater temporal variation in the results of TDS samples from HHD10-R3-MW18F, than in bulk conductivity in well PB-1822. Water samples collected at a depth of $90 \mathrm{ft}$ in monitoring well HHD10-R3-MW18F, for example, indicated that the TDS and chloride concentrations varied by 35 percent (appendix 1), yet at this same depth, the TSEMIL dataset from well PB-1822 indicated no temporal change in bulk conductivity during April 2012-February 2013.

The TDS and chloride concentrations of water samples from a depth of $60 \mathrm{ft}$ in the long-screened well HHD10-R2-MW4F varied by 76 and 75 percent, respectively (appendix 1; fig. $6 B$ ), yet the chloride concentration of water samples from collocated well GL-332S varied through time by only about 16 percent in the depth interval 55 to $60 \mathrm{ft}$ (fig. $4 A$; appendix 2). At a depth of $90 \mathrm{ft}$, water samples from well HHD10-R2-MW4F indicated that TDS and chloride concentrations varied by 80 and 89 percent, respectively, yet the TSEMIL dataset from well GL-332 indicated little or no temporal change in bulk conductivity at this depth (fig. $6 A-B$ ). The TDS concentration of the sample collected at a depth of $120 \mathrm{ft}$ in January 2013 in well HHD10-R2-MW4F was about 6 times that of the sample collected in August 2012, yet the TSEMIL dataset from well GL-332 indicated only a minor increase in bulk conductivity during the study (fig. $6 A-B$ ). A possible explanation for this difference is dilution of the August 2012 sample from well HHD10-R2-MW4F by downward flow of less saline water within the open well bore.

Water samples collected during April 2012-January 2013 from the long-screened monitoring well HHD08-R1C-MW8D indicated an increase of $3,000 \mathrm{mg} / \mathrm{L}$ in the TDS concentration at a depth of $50 \mathrm{ft}$ and a variation in TDS concentration of 22,000 to $27,000 \mathrm{mg} / \mathrm{L}$ at $130 \mathrm{ft}$ (appendix 1; fig. 12B). These depths do not correspond to the depths sampled in collocated well cluster PB-1818S/PB-1818, therefore, water sample results cannot be compared. The TSEMIL dataset from well PB-1818 indicated increases in bulk conductivity at 50 and $130 \mathrm{ft}$ during this period (fig. 12A). Although the changes in TDS samples from HHD08-R1C-MW8D corresponded to changes in the TSEMIL dataset from the collocated well PB-1818, these changes are much smaller than some of the changes observed in other long-screened wells at locations where no seepage barrier had been installed. The data from the collocated well clusters showed little or no changes; therefore, it would be difficult to evaluate any effects that might have resulted from the installation of the seepage barriers using data from the long-screened wells alone.

\section{Conclusions}

A seepage barrier is being installed along the Herbert Hoover Dike (HHD), around Lake Okeechobee, to prevent its failure. Monitoring was initiated to determine if the saltwater interface was disturbed as groundwater flow was altered by the seepage barrier. The monitoring network consisted of 20 shallow and deep, short-screened interval monitoring wells installed at 10 sites, from which water samples and timeseries-electromagnetic-induction-log (TSEMIL) datasets were collected. Water samples were collected from the monitoring wells, following the removal of 3 to 5 well volumes of water to ensure that the samples were representative of water in the aquifer rather than that within the well bore. At five of the locations monitored by the U.S. Geological Survey, the U.S. Army Corps of Engineers and the International Analytic Group monitored collocated long-screened interval wells by collecting water samples using a straddle packer system.

Monitoring results indicate that the seepage barrier may be altering groundwater flow and disturbing the layer of saltwater within the surficial aquifer. Changes in bulk conductivity values in the TSEMIL datasets, closely associated with the depth of the seepage barrier, were evident at all of the monitoring locations where the seepage barrier was installed to a depth near to, or below, that of the top of the saltwater interface. The TSEMIL datasets collected from deep monitoring wells PB-1815, PB-1816, PB-1818, and PB-1819 showed (1) decreases in the depth of the saltwater interface of 2 to 19 feet (ft), (2) increases in bulk conductivity extending from depths 0 to $29 \mathrm{ft}$ above to 0 to $18 \mathrm{ft}$ below the bottom of the seepage barrier, and (3) dilution of the saltwater in the aquifer extending from depths of 11 to $18 \mathrm{ft}$ to 34 to $73 \mathrm{ft}$ below the bottom of the seepage barrier. These changes are probably the result of the diversion of groundwater flow under the seepage barrier, where it is causing saltwater from deeper in the aquifer to move upward at the monitoring locations. This groundwater flow also appears to be diluting saltwater in the aquifer at depths well below the seepage barrier.

The TSEMIL dataset from monitoring well PB-1817 indicated slight increases in bulk conductivity, but the depth to the top of the saltwater interface has not changed substantially. The lack of change may be related to the monitoring well location, because it is $1,750 \mathrm{ft}$ from the HHD, adjacent to the West Palm Beach Canal, and located near a 500-ft gap in the seepage barrier. Seepage of freshwater from the canal may have been a factor in preventing decreases in the depth of the saltwater interface at this location. A potential increase in groundwater flow through the seepage barrier gap could have transported more saline groundwater from the north and south to well PB-1817 without establishing an upward groundwater flow gradient at the well location that could cause the saltwater interface to become shallower.

At monitoring well location PB-1820, where the depth of the saltwater interface is $75 \mathrm{ft}$ below the bottom of the seepage barrier, there was a slight increase in the depth of the saltwater interface and a slight decrease in bulk conductivity just above 
the interface. These changes may have been caused by deeper circulation of fresh groundwater resulting from the installation of the seepage barrier. Where the seepage barrier was not installed, the changes in bulk conductivity and chloride concentration were generally minor. At these locations, therefore, water conductivity does not appear to have changed substantially in the aquifer.

At the locations of monitoring wells GL-332, HE-1145, PB-1821, and PB-1822, where a seepage barrier had not been installed, there was little or no change in the depth of the saltwater interface through time. The TSEMIL dataset from well PB-1821 indicated virtually no change in bulk conductivity, except near the water table. The seepage barrier ends $1,150 \mathrm{ft}$ north of this well, and the well is located 1,050 ft west of the HHD and on the Lake Okeechobee side of the dike.

The results of water sampling to evaluate the concentration of total dissolved solids in monitoring wells HHD10-R2-MW4F, HHD10-R2-MW18F, and HHD10-R3-MW18F varied by as much as 20 to 85 percent, respectively, even though a seepage barrier had not been installed at these well locations. These variations were much greater than those indicated by chloride concentration sampling and electromagnetic-induction logging in collocated short-screened monitoring-well clusters PB-1822S/PB-1822 and GL-332S/GL-332. The saltwater interface evident in samples and TSEMIL datasets from well cluster HE-1145S/HE-1145 could not be identified in the information collected from the collocated well HHD10-R2-MW18F.

The variability of water-sample results from the long-open-interval wells could be explained by well-bore flow under ambient conditions, which has been shown to alter the distribution of salinity in the well relative to that in the aquifer. Even though the long-screened wells were purged prior to sampling, it is unlikely that this would remove all water that might have flowed through the well bore and into the aquifer. It is also possible that when the well is pumped during sampling, water may flow vertically through the annulus between the well screen and wall of the borehole, because there are no seals to prevent this flow.

\section{References Cited}

Abtew, Wossenu, and Iricanin, Nenad, 2008, Hurricane effects on south Florida water management system-A case study of Hurricane Wilma of October 2005: Journal of Spatial Hydrology, v. 8, no. 1, 21 p.

Bromwell, L.G., Dean, R.G., and Vick, S.V., 2006, Report of expert review panel-Technical evaluation of Herbert Hoover Dike, Lake Okeechobee, Florida: BCI Engineers \& Scientists, Inc., 77 p.
Johnson, C.D., Haeni, F.P., Lane, J.W., and White, E.A., 2002, Borehole-geophysical examination of the University of Connecticut landfill, Storrs, Connecticut: U.S. Geological Survey Water-Resources Investigations Report 01-4033, $42 \mathrm{p}$.

Lloyd's, 2010, The Herbert Hoover Dike, a discussion of the vulnerability of Lake Okeechobee to levee failure; cause, effect and future: Lloyd's, Risks Lloyd's emerging risks team report, 21 p., accessed April 4, 2014, at http:// www.lloyds.com/ /media/Lloyds/Reports/360/360\%20 Climate\%20reports/Lake_Okeechobee_Report.pdf.

Oki, D.S., and Presley, T.K., 2008, Causes of borehole flow and effects on vertical salinity profiles in coastal aquifers: Program and proceedings book, 20th Salt Water Intrusion Meeting, June 23-27, 2008, p. 170-173, accessed November 14, 2012, at http://conference.ifas.ufl.edu/swim/ papers.pdf.

Prinos, S.T., Wacker, M.A., Cunningham, K.J., and Fitterman, D.V., 2014, Origins and delineation of saltwater intrusion in the Biscayne aquifer and changes in the distribution of saltwater in Miami-Dade County, Florida: U.S. Geological Survey Scientific Investigations Report 2014-5025, 101 p., Also available at $h t t p: / / d x$.doi.org/10.3133/sir20145025.

Reese, R.S., and Wacker, M.A., 2009, Hydrogeologic and hydraulic characterization of the surficial aquifer system, and origin of high salinity groundwater, Palm Beach County, Florida: U.S. Geological Survey Scientific Investigations Report 2009-5113, 83 p. (appendixes on CD).

Reilly, T.E., Franke, O.L., and Bennett, G.D., 1989, Bias in groundwater samples caused by wellbore flow: Hydraulic Engineering Journal, v. 115, no. 2, p. 270-276.

Runkel, A.C., Tipping, R.G., and Anderson, J.R., 2008, Washington County landfill logging project-Borehole geophysical tests for presences of fracture flow at a perflourochemical contamination site: Minnesota Geological Survey, Open-File Report 08-07, 9 p., plus figs. and 1 app.

Shalev, Eyal, Lazar, Ariel, Wollam, Stuart, Kington, Shushanna, Yechieli, Yoseph, and Gvirtzman, Haim, 2009, Biased monitoring of fresh water-salt water mixing zone in coastal aquifers: Ground Water, v. 47, no. 1, p. 49-56.

Shapiro, A.M., 2002, Cautions and suggestions for geochemical sampling in fractured rock: Groundwater Monitoring \& Remediation, v. 22, no. 3, p. 151-164.

U.S. Army Corps of Engineers, n.d., Lake Okeechobee and the Herbert Hoover Dike-A summary of the engineering evaluation of seepage and stability problems at the Herbert Hoover Dike: U.S. Army Corps of Engineers Technical Report, 19 p., accessed January 7, 2015, at http://static. cbslocal.com/station/wfor/files/HooverDike.pdf. 
U.S. Army Corps of Engineers, 2013, Herbert Hoover DikeRehabilitation: U.S. Army Corps of Engineers Fact Sheet, 2 p., accessed April 4, 2014, at http://www.saj.usace. army.mil/Portals/44/docs/FactSheets/HHD_FS_Rehab_ Spring2013_508.pdf.

U.S. Environmental Protection Agency, 2014a, Environmental Geophysics - Electrical Methods: U.S. Environmental Protection Agency, accessed December 8, 2014, at http:// www.epa.gov/esd/cmb/GeophysicsWebsite/pages/referencel methods/Surface_Geophysical_Methods/Electrical_ Methods/.

U.S. Environmental Protection Agency, 2014b, Secondary drinking water regulations; guidance for nuisance chemicals: U.S. Environmental Protection Agency Report 816-f-10-079, accessed December 8, 2014, at http://water. epa.gov/drink/contaminants/secondarystandards.cfm. 
Manuscript approved December 18, 2014

Prepared by the Raleigh Publishing Service Center Michael Deacon, Editor

Kimberly Swidarski, Illustrations and layout

For more information about this publication, contact: Director

U.S. Geological Survey

Caribbean-Florida Water Science Center

4446 Pet Lane, Suite 108

Lutz, FL 33559

(813) 498-5000

or visit our Web site at

http://fl.water.usgs.gov 


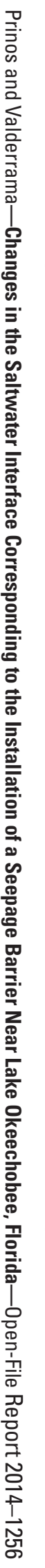

